\title{
TGF- $\beta$ and WNT signaling pathways in cardiac fibrosis: non-coding RNAs come into focus
}

\author{
Fatemeh Yousefi ${ }^{1}$, Zahra Shabaninejad ${ }^{2,3}$, Sina Vakili ${ }^{4}$, Maryam Derakhshan ${ }^{5}$, Ahmad Movahedpour ${ }^{6,7}$, \\ Hamed Dabiri ${ }^{1,8}$, Younes Ghasemi ${ }^{3,9}$, Maryam Mahjoubin-Tehran ${ }^{10,11}$, Azin Nikoozadeh ${ }^{12}$, Amir Savardashtaki ${ }^{3,6^{*}}$, \\ Hamed Mirzaei ${ }^{13^{*}}$ and Michael R. Hamblin ${ }^{14,15^{*}}$
}

\begin{abstract}
Cardiac fibrosis describes the inappropriate proliferation of cardiac fibroblasts (CFs), leading to accumulation of extracellular matrix (ECM) proteins in the cardiac muscle, which is found in many pathophysiological heart conditions. A range of molecular components and cellular pathways, have been implicated in its pathogenesis. In this review, we focus on the TGF- $\beta$ and WNT signaling pathways, and their mutual interaction, which have emerged as important factors involved in cardiac pathophysiology. The molecular and cellular processes involved in the initiation and progression of cardiac fibrosis are summarized. We focus on TGF- $\beta$ and WNT signaling in cardiac fibrosis, ECM production, and myofibroblast transformation. Non-coding RNAs (ncRNAs) are one of the main players in the regulation of multiple pathways and cellular processes. MicroRNAs, long non-coding RNAs, and circular long non-coding RNAs can all interact with the TGF- $\beta$ NNNT signaling axis to affect cardiac fibrosis. A better understanding of these processes may lead to new approaches for diagnosis and treatment of many cardiac conditions.
\end{abstract}

Keywords: Cardiac fibrosis, TGF- $\beta$ /WNT signaling, Non-coding RNAs

\section{Introduction}

Cardiac fibrosis and abnormal tissue remodeling are pathological findings in many cardiac disorders, such as myocardial infarction, hypertension, myocarditis, cardiac hypertrophy, and dilated cardiomyopathy. These conditions are associated with considerable morbidity and mortality [1-3]. The process of cardiac fibrosis is

\footnotetext{
*Correspondence: Dashtaki63@gmail.com; HAMBLIN@helix.mgh.harvard.edu; mirzaei-h@kaums.ac.ir; h.mirzaei2002@gmail.com

${ }^{3}$ Pharmaceutical Sciences Research Center, Shiraz University of Medical Sciences, Shiraz, Iran

${ }^{13}$ Research Center for Biochemistry and Nutrition in Metabolic Diseases, Institute for Basic Sciences, Kashan University of Medical Sciences, Kashan, IR, Iran

${ }^{14}$ Wellman Center for Photomedicine, Massachusetts General Hospital, Harvard Medical School, 40 Blossom Street, Boston, MA 02114, USA Full list of author information is available at the end of the article
}

characterized by a disproportionate accumulation of extracellular matrix (ECM) components. The transformation of cardiac fibroblasts (CFs) to myofibroblasts is the key step in this process, and plays a critical role in the development of fibrosis [4]. When cardiomyocytes die over a period of several days following a sudden cardiac injury, activated myofibroblasts trigger the formation of a fibrotic scar in the affected cardiac muscle [5]. Experimental and clinical evidence has suggested that the transformation of CFs could be regulated by the transforming growth factor beta (TGF- $\beta$ ) and WNT (wingless int1) signaling pathways. Experimental models have shown increased expression of TGF- $\beta$ and WNT proteins, as key pro-fibrotic factors in cardiac fibrosis [6-8]. Noncoding RNAs (ncRNAs) can be classified into several different types, including small microRNAs 
(miRNAs or miRs; $\sim 22$ nucleotides), long noncoding RNAs (lncRNAs; $>200$ nucleotides) and circular long noncoding RNAs (circRNAs; $>200$ circular nucleotides) $[9,10]$. All these ncRNAs have been implicated in the regulation of specific cellular signaling pathways, such as TGF- $\beta$ and WNT, that act to regulate cytokine secretion and extracellular matrix synthesis [11-13]. A growing body of evidence points to cross-regulation between these two pro-fibrotic pathways mediated via ncRNAs, and its involvement in the pathophysiology of cardiac fibrosis. Understanding these mechanisms will be important to develop new therapeutic agents for treatment of cardiac fibrosis [14-17]. In this review, we will first provide an overview of TGF- $\beta$ and WNT signaling, and their regulation, followed by a description of their role in the pathogenesis of cardiac fibrosis. Next, we summarize some recent experimental evidence for the involvement of TGF- $\beta$ and WNT signaling in vascular and cardiac remodeling during fibrosis. Finally, the role of ncRNAs, including miRNAs, lncRNAs, and circRNAs, in TGF- $\beta$ and WNT signaling in the heart. This is a relatively new field that may provide new avenues for the prevention and treatment of cardiac fibrosis.

\section{TGF- $\beta$ signaling}

A growing body of evidence indicates that members of the TGF- $\beta$ family can play a major role in a wide range of processes related to cardiac pathophysiology, including cardiac repair, hypertrophy, fibrotic remodeling, fibroblast activation, and extracellular matrix deposition [18-23]. The TGF- $\beta$ family is comprised of 33 members, which are multifunctional cytokines interacting with TGF- $\beta$ receptors to trigger signaling cascade responses in cells [24]. In mammals, the TGF- $\beta$ isoforms (TGF- $\beta 1$, $\beta 2$, and $\beta 3$ ) are encoded by three different genes, that are located on separate chromosomes [25-27]. Although in vitro studies have suggested that the three isoforms have similar properties, knockout experiments in mice have shown that each TGF- $\beta$ isoform exerts distinct effects in tissue development and differentiation in vertebrates [28-31]. TGF- $\beta$ is initially secreted as a latent complex consisting of three proteins, including TGF- $\beta$, latency-associated protein (LAP) and latent TGF- $\beta$ binding proteins (LTBPs) so that it is inactive in its latent form. This complex is proteolytically cleaved and activated by an integrin-mediated process [32-34]. Upon binding to their receptor, TGF- $\beta$ s can activate various processes which can be Smad-dependent (canonical response) or Smad-independent (noncanonical response). The Smad-dependent TGF- $\beta$ signaling pathway is much better documented. Once activated the TGF- $\beta$ can bind to heterodimeric receptors (consisting of TGF- $\beta$ type I and TGF- $\beta$ type II receptors) and initiate a signaling cascade mediated by the Smad family of transcription factors [35-37]. In the presence of the TGF- $\beta$ ligand, TGF- $\beta$ receptor I kinase promotes phosphorylation of the receptor-activated Smads (R-Smads, Smad2 and 3), which mediates the translocation of $\mathrm{p}$-Smad into the nucleus via binding to the common mediator, Smad4 [37]. In the nucleus, the $\mathrm{R}-\mathrm{Smad} / \mathrm{Smad} 4$ complex associates with the transcriptional cofactor p300 and with Fast-1, a nuclear DNA binding protein belonging to the Fast family. This complex binds to DNA, leading to increased expression of the downstream effectors of the TGF- $\beta$ signaling pathway $[38,39]$. There are fundamental differences between the processes mediated by Smad2 and Smad3. Smad2 is required for normal development processes, whereas Smad3 is required for TGF- $\beta$-induced gene expression. Microarray analysis in adult Smad3 ${ }^{-} /^{-}$ and $\mathrm{Smad}^{+}{ }^{+}{ }^{+}$mice revealed that TGF- $\beta$ did not induce any transcription in $\mathrm{Smad3}^{-} /^{-}$fibroblasts [40]. Intriguingly, in a recent report, Smad2 homozygous mice $\left(\mathrm{Smad} 2^{-} I^{-}\right)$were not viable during embryogenesis, suggesting that Smad2 is required for normal development [41]. Two inhibitory Smads (I-Smad), named Smad6 and Smad7, do not allow R-Smad phosphorylation, and prevent subsequent nuclear translocation of $\mathrm{R}-\mathrm{Smad} / \mathrm{Smad} 4$ heterocomplexes, because they compete for the normal binding of Smad2 and Smad3 to the TGF- $\beta$ R1 [42]. After completion of the Smad transcriptional activity, coactivator p300 facilitates an interaction between Smad3 and the E3 ligase complex causing Smad3 ubiquitination, leading to its degradation by the ubiquitinproteasome pathway $[43,44]$.

In addition, TGF- $\beta$ can also result in direct activation of a non-canonical response via three different pathways, namely the PI3K/Akt, RhoA-ROCK axis and MAPK cascades. In the PI3K/Akt pathway, activated TGF- $\beta$ type I receptor stimulates a signaling cascade involving phosphatidylinositol-3-kinase (PI3K) and protein kinase B (also known as Akt). In this pathway, PI3K activation mediates phosphorylation and activation of Akt kinase, which in turn modulates several downstream effectors, such as the mammalian target of rapamycin (mTOR), glycogen synthase kinase- $3 \beta$ (GSK-3 $\beta$ ) and many others $[45,46]$. The second pathway involves Rho-associated protein kinases (ROCKs) which are coiled-coilcontaining protein kinases existing in two isoforms, ROCK1, and ROCK2 [47]. Experiments have confirmed the importance of ROCKs in regulation of various cellular functions, especially cardiac fibrogenesis $[48,49]$. It has been demonstrated that inhibition of ROCK prevented cardiac fibrosis in response to transverse aorta constriction (TAC) and myocardial infarction (MI) [50]. In the third pathway, mitogen- activated protein kinases (MAPKs) transmit the signal from the cell membrane to the nucleus, and regulate gene expression through extracellular signal-regulated kinase 1 and 2 (Erk1/2 or p44/ 
42), c-Jun N-terminal kinases (JNKs), and the p38 isoforms $(\alpha, \beta, \gamma$, and $\delta)$ [51]. The Smad-independent activation of MAPKs was confirmed by a study that found that activation of MAPKs occurred in TGF- $\beta$ treated cells, even in the presence of Smad4-deficient or dominant-negative Smads [52].

\section{WNT signaling}

Several publications have indicated the importance of the WNT signaling cascade in normal development and the pathogenesis of many diseases [53-56]. WNT ligands are highly conserved secreted glycoproteins, which are transcribed from 19 genes in mammals, and are subdivided into 12 conserved subfamilies [57]. A family of seven transmembrane receptors called Frizzled (Fz) act as receptors for WNT ligands [58]. WNT ligands engage the $\mathrm{Fz}$ receptors and the low-density-lipoprotein-receptor-related proteins (LRP) 5 and LRP6 act as co-receptors resulting in the formation of a complex at the plasma membrane. Activated $\mathrm{Fz}$ receptors activate not only the $\beta$-catenin-dependent pathway, but also trigger a number of $\beta$-catenin-independent signaling cascades.

In the WNT/ $\beta$-catenin signaling pathway, the activated Fz/LRP complex activates the Dishevelled (DVL) protein, which interacts with a "destruction complex" comprised of axin, adenomatous polyposis coli (APC), glycogen synthase kinase 3 (GSK3), casein kinase 1 (CK1), plus the ubiquitin ligase, $\beta$-TrCP. This destruction complex normally causes the ubiquitination and consequent destruction of $\beta$-catenin [59-61]. When the destruction complex binds to DVL it is inhibited, and $\beta$ catenin escapes from ubiquitination and degradation $[62,63]$. Eventually, the stabilized $\beta$-catenin translocates to the nucleus where it activates WNTresponsive genes, by binding to $\mathrm{T}$-cell factor/lymphoid enhancer-binding factor-1 (TCF/Lef-1) transcription factors, and other co-factors, such as p300 and CREB binding protein (CBP) [56].

In the $\beta$-catenin-independent signaling pathway, WNT4, WNT5a or WNT11 ligands can stimulate the Fz receptor to trigger gene transcription, by activating the planar cell polarity pathway, and a calcium-dependent pathway. Signal transduction through the WNT/calcium cell polarity pathway typically consists of protein kinase $\mathrm{C}$ (PKC), calmodulin kinase II and calcineurin. Calcineurin is a $\mathrm{Ca}^{2}{ }^{+-}$sensitive enzyme activated by $\mathrm{Ca}^{2+}$ release which results in elevated nuclear levels of the AP-1/c-Jun transcription factor [64, 65]. In the planar cell polarity pathway, certain MAPKs (JNK and ERK1/2 kinases) and the RhoA-ROCK axis act as important regulators to trigger signaling. In this pathway, WNT proteins activate Rho signaling and Jun $\mathrm{N}$-terminal kinase (JNK) through DVL, leading to the modulation of cellular activity and polarity via ATF/CREB activation [66].
Endogenous WNT antagonists, such as the Dikkopf (DKK) and secreted frizzled-related protein (sFRP) families can regulate WNT signaling [67-69]. Many studies have emphasized the key role of the WNT signaling pathway in cardiac fibrosis, and it has been suggested that regulation of signaling pathways might be a useful pharmacological target for treatment of cardiac disease [70-72].

\section{Crosstalk between the TGF- $\beta$ and WNT signaling pathways}

Recent studies have highlighted the extensive cross-talk between the TGF- $\beta$ and WNT pathways, which could be responsible for the transcription of pro-fibrotic genes. These pathways could create a positive feedback loop or a negative feedback loop that impacts on the transcriptional activity of other signaling cascades. For instance, loss of the WNT co-receptor LRP5, in bleomycininduced lung fibrosis decreased the expression of TGF$\beta 1$, and attenuated the induction of fibrosis [73]. Consistently, over-expression of a constitutively active TGF$\beta$ receptor type $I$ in a mouse model (Ad-TBRI ${ }^{\text {act }}$-induced fibrosis) enhanced the stability and nuclear accumulation of $\beta$-catenin in primary cultured fibroblasts. These results showed that TGF- $\beta$ activated the canonical WNT pathway through a decrease in Dkk-1 via MAPKp38, and this could be a major molecular mechanism for the activation of the canonical WNT pathway [6]. In addition, it was reported that sirtuin 3 (SIRT3) can increase the enzymatic activity of GSK3, resulting in the blockage of TGF- $\beta$ expression in tissue fibrosis. The SIRT3 deficiency induced GSK3 $\beta$ hyperacetylation resulting in reduced GSK3 $\beta$ activity and lower phosphorylation of Smad3, and $\beta$-catenin activation. These events lead to stabilization and activation of Smad 3 and $\beta$-catenin transcription factors involved in the tissue fibrosis process [74]. In addition, upon TGF- $\beta$ stimulation, the Axin, WNT scaffold protein, can promote Smad7 degradation by forming a complex with Smad7 and the E3 ubiquitin ligase Arkadia [75]. Another report revealed that Axin facilitated Smad3 binding to the type I receptor to promote the tail-phosphorylation of Smad3, which induced the transcription of profibrotic genes [76].

Furthermore, the microRNA, miR-29 inhibited the synthesis of ECM caused by TGF $\beta 1$, through inhibition of WNT3a/ $/$-catenin signaling pathway in human orbital fibroblasts [77]. Yeast two-hybrid and GST-pull down assays showed a physical interaction between DVL-1 and Smad3. Stimulation of the TGF $\beta$ pathway leads to an increase in DVL-1, and Smad3 binding in vivo [78]. Cotreatment with both WNT-3a conditioned medium, and TGF $\beta$ led to enhancement of nuclear $\beta$-catenin, whereas TGF $\beta$ alone had no effect. Moreover, Smad3 over- 
expression enhanced the ability of WNT-3a to increase transcription, suggesting that $\operatorname{Smad} 3$ is required for the effects of TGF- $\beta$ on gene transcription [79]. The ability of TGF- $\beta$ to activate the canonical WNT signaling pathway, and the functional impact of this mechanism on fibrotic processes has been reported in many organs, as well as the heart $[6,80-82]$. In summary, these data point to the important role of TGF- $\beta$ signaling in the activation of the $\beta$-catenin-dependent pathway, and conversely, the role of the $\mathrm{WNT} / \beta$-catenin signaling pathway to trigger TGF- $\beta$ signaling. Taken together, it appears that mutual co-activation of these two pathways is required to trigger the actual fibrotic response.

\section{Cardiac fibrosis}

Cardiac fibrosis is characterized by the increased activity of cardiac fibroblasts, resulting in the accumulation of ECM proteins (e.g. collagen I and III), which produce increased myocardial stiffness, and thereby increase the risk of heart failure and sudden cardiac death [83]. Cardiac fibrosis commonly occurs in several types of cardiovascular disease, such as those caused by diabetes, ischemia, aging, and inherited cardiomyopathy, which cause considerable morbidity and mortality [1-3]. Healthy heart tissue consists of endothelial cells, vascular smooth muscle cells, fibroblasts, and myocytes [84-86]. The alteration of the collagen matrix results from dysregulation of the balance between pro-fibrotic and anti-fibrotic factors, including cytokines, chemokines, hormones, growth factors, and proteases. This dysregulation causes a swing in the balance, leading to excess synthesis or inhibition of degradation [87]. Fibroblasts are involved in collagen formation and degradation, and any derangement in this process leads to collagen expansion and myocardial fibrosis [88]. The key event in cardiac fibrosis is the transformation of cardiac fibroblasts (CFs) into myofibroblasts, which are involved in ECM production, and accelerating the fibrotic process following cardiac injury. After cardiac ischemia, cardiomyocytes gradually die over a period of several days starting after myocardial infarction, and then myofibroblasts replace the dead cells, and largely produce the fibrotic scar [5]. There are two main stages in myofibroblast transformation: in the first stage, small adhesion complexes and stress-fiber network formation occurs to develop proto-myofibroblasts from fibroblasts, and to facilitate the migration of these cells into the injured tissue. In the second stage, these proto-myofibroblasts convert to mature myofibroblasts which secrete alpha-smooth muscle actin ( $\alpha$-SMA) and cadherin- 11 by approximately $20-30$ $h$ following cardiac injury [89-91]. Activated myofibroblasts deposit large amounts of ECM proteins in the infarcted area [92]. In cardiovascular disease, myocardial fibrosis can be divided into three stages: mild diffuse fibrosis, severe diffuse fibrosis, and segmental fibrosis.

Finding an effective treatment for myocardial fibrosis is a major clinical challenge, which may dramatically improve the survival rate and the quality of life in patients. Cardiac magnetic resonance (CMR) imaging has been used to evaluate the extent of diffuse myocardial fibrosis, and for monitoring patients with cardiac fibrosis [93-95]. In one study by McCrohon and colleagues, myocardial fibrosis was assessed in patients suffering from dilated cardiomyopathy (DCM) using gadoliniumCMR demonstrating high sensitivity, specificity, and good spatial resolution. The results suggested that approximately one third of patients with DCM may have myocardial scarring or fibrosis [96]. Therefore, CMR imaging techniques may be used to delineate foci of fibrosis in patients with DCM. Myocardial fibrosis is associated with electrical dysfunction that leads to ventricular arrhythmias in tricuspid atresia patients [97]. Ventricular myofiber disorganization and interstitial fibrosis have been demonstrated in patients with tetralogy of Fallot [98]. A study revealed increased macroscopic fibrosis in the left ventricles (LV) of deceased patients with congenital aortic stenosis and coarctation [99]. Also, LV fibrosis has been detected in patients with idiopathic DCM who only had mild symptoms. The data suggested that collagen accumulation might be responsible for the impaired LV diastolic function found in these patients [100]. Various alterations in molecular pathways and cellular effectors have been shown to occur in various cardiac fibrotic conditions, and it is important to assign the relative contribution(s) of each pathway, and the therapeutic implications. Therefore, the effectiveness of antifibrotic strategies requires a better understanding of the mechanisms of cardiac fibrosis, which may depend on the underlying etiology, severity and extent of disease.

\section{The role of TGF $\beta$ and WNT signaling in cardiac fibrosis} Myofibroblasts expressing expressed $\alpha$-SMA (smooth muscle actin) are mainly involved in the excessive synthesis and degradation of collagen in cardiac fibrosis [4, 101]. Following a cardiac injury, fibroblasts transdifferentiate into myofibroblasts, which are normally absent in the healthy heart. Myofibroblasts are in between a fibroblast and a smooth muscle cell in phenotype [102, 103]. Myofibroblasts mainly secrete ECM proteins, such as periostin, collagens I and III, and fibronectin, and also a number of cytokines which regulate the inflammatory response at the injury site [89]. In heart disease, fibrotic remodeling associated with cellular and molecular mechanisms, leads to disturbance of cardiac function in different ways. Myocardial fibroblasts are stimulated both mechanically and chemically to undergo differentiation into the myofibroblast phenotype [104]. The TGF- $\beta$ and 
WNT signaling pathways are two key regulators of myofibroblast biology in cardiac fibrosis [56, 105-107]. High expression levels of TGF- $\beta 1$ (a prototypical fibrogenic cytokine) has been reported during cardiac fibrosis both in humans and experimental models $[108,109]$. The increase in TGF- $\beta$ causes nuclear accumulation of Smad2/ 3 in myofibroblasts, and decreases the inhibitory Smad6 and Smad7, thereby inducing the activation of numerous pro-fibrotic genes [21, 110, 111]. The resistance of fibroblasts isolated from Smad3 -/- mouse embryos to TGF$\beta 1$ induction of ECM proteins, confirmed that Smad3 mediated TGF- $\beta$ transactivation of these ECM promoters $[40,112]$. In the injured heart, the Smad3 signaling cascade may be the first step in myofibroblast differentiation by promoting $\alpha$-SMA transcription [113]. In $\alpha$-SMA-positive myofibroblasts, TGF $\beta 1$ could upregulate matrix proteins (such as ED-A fibronectin) and increase the deposition of collagen sub-types (such as collagens I, III, and VI) by regulating the levels of plasminogen activator inhibitor (PAI)-1 and tissue inhibitor of metalloproteinases (TIMPs), and also by regulating the levels of other pro-fibrotic cytokines [114-116]. Collagen type VI plays a role in cardiac remodeling by increasing myofibroblast differentiation, whereas collagen types I and III stimulate the proliferation of CF via increasing ERK1/2 activity [117]. WNT/ $\beta$-catenin signaling is enhanced in areas of scar formation, and in epicardial activation in mouse models [118]. Activation of the $\mathrm{WNT} / \beta$-catenin pathway by TGF- $\beta$ is well-documented. TGF- $\beta$ increases Akt phosphorylation through PI3K activation, thus inactivating GSK3 $\beta$ (an enzyme involved in $\beta$-catenin degradation), which promotes cardiac fibrosis [119]. In recent years, a number of reports have indicated that the canonical WNT/ $\beta$-catenin pathway, and Smad-dependent TGF- $\beta$ signaling are involved in the stimulation of myofibroblast proliferation and differentiation, thus promoting fibrogenesis [120, 121]. WNT3a can promote migration in cultured fibroblasts, as well as the adoption of a myofibroblast-like phenotype, in part by up-regulation of TGF- $\beta$ signaling through Smad2. WNT3a-induced $\alpha$-SMA expression was reversed following knockdown of $\beta$-catenin, suggesting that fibrosis was dependent on canonical WNT signaling through $\beta$ catenin [14]. GSK-3 $\beta$ exerts a novel and central role in regulating myocardial fibrotic remodeling via modulation of canonical TGF- $\beta 1$ signaling through direct interaction with Smad-3. Moreover, genetic and pharmacological approaches have demonstrated that inhibition of GSK-3 $\beta$ can induce the transformation of fibroblasts to myofibroblasts [122]. In cardiac fibroblasts, overexpression of FGF23 promoted fibroblast proliferation through activation of $\beta$-catenin signaling, leading to TGF- $\beta$ up-regulation [15]. In primary cardiac fibroblasts, lack of endogenous sFRP-1 increased $\alpha$ SMA and collagen expression, and promoted differentiation of fibroblasts into myofibroblasts [71]. Over-expression of sFRP2 significantly reduced ventricular fibrosis, and improved cardiac function in vivo [123]. On the other hand, sFRP2 antibody therapy decreased apoptosis and fibrosis, and improved cardiac function in a hamster model of heart failure [124]. In agreement with this, mice lacking the sFRP2 gene that were subjected to myocardial infarction, exhibited a reduction in cardiac fibrosis [125]. These findings suggest that sFRPs have multiple modes of action in fibrotic processes. In a WNT1 Cre transgenic mouse model subjected to myocardial ischemia, WNT 1 expression occurred within 2 days following ischemia, with high expression levels found in both epicardial cells and cardiac fibroblasts. Experimental models using CF-specific loss of $\beta$-catenin, or exogenous over-expression of WNT1, have suggested that canonical WNT signaling can induce collagen gene expression during cardiac fibrosis. Chromatin immunoprecipitation (ChIP) assays with an anti- $\beta$-catenin antibody, showed that the $\beta$-catenin/LEF/TCF transcriptional complex directly bound to ECM genes in CFs [126]. In agreement with these studies, Dickkopf-3 (DKK3), a WNT signaling pathway inhibitor, attenuated cardiac fibrosis in cardiac hypertrophy induced by administration of angiotensin II (AngII), by promoting AngII degradation. DKK3 inhibited the phosphorylation of the metalloproteinase enzyme known as "a disintegrin and metalloproteinase 17" (ADAM17), which in turn increased angiotensin converting enzyme 2 expression, and subsequently increased AngII degradation. AngII degradation was triggered by the inhibition of GSK-3 $\beta$ and $\beta$-catenin, and the decreased translocation of $\beta$ catenin to the nucleus. On the other hand, DKK3 knockdown by siRNA achieved the opposite effects [127]. The blocking of the TGF $\beta$ and WNT pathways prevented the development of fibrosis in animal models, but whether these two signaling pathways contribute to chronic pathologic fibrosis in humans is still unknown. Figure 1 and Table 1 illustrate the WNT and TGF $\beta$ signaling pathways which have been associated with the pathogenesis of cardiac fibrosis.

\section{Non-coding RNAs}

ncRNAs play important roles in many cellular processes. Based on nucleotide length, they are classified into: small miRNAs (22 nucleotides) and lncRNAs (> 200 nucleotides) $[138,139]$. Circular RNAs (circRNAs) are a new type of ncRNAs that can regulate gene expression and protein production by acting as an miRNA sponge [140-142]. These three groups of ncRNAs can be detected in blood and other body fluids, such as urine and breast milk, and can act as powerful tools for detection and therapy of cardiac diseases, including cardiac fibrosis 


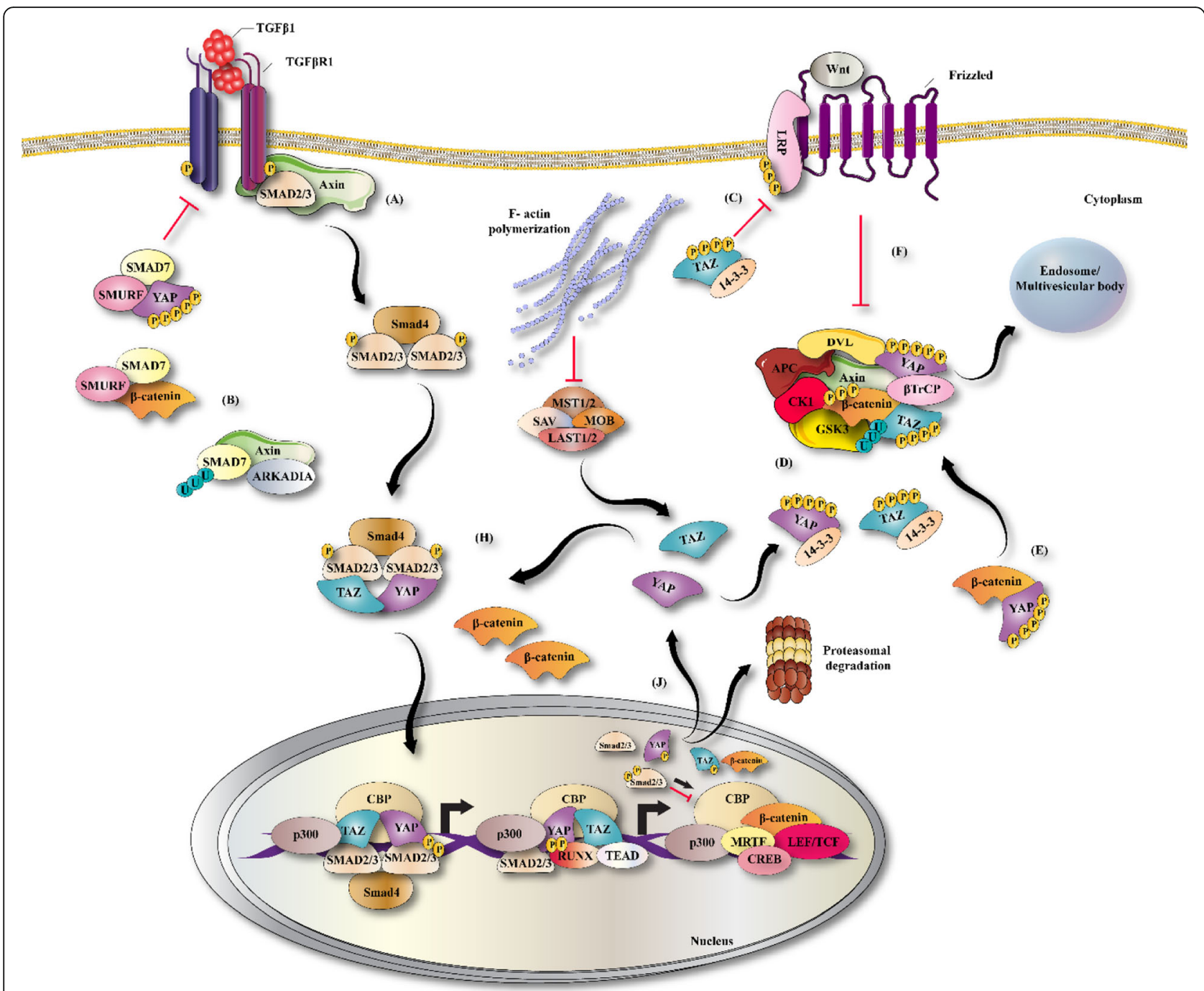

Fig. 1 Role of WNT/TGF $\beta$ signaling pathways in pathogenesis of cardiac fibrosis. Simplified scheme showing the WNT/ $\beta$-catenin pathway, and Smad-dependent TGF- $\beta$ signaling are involved in the stimulation of myofibroblast proliferation and differentiation, thus promoting fibrogenesis

$[4,50,143]$. The function of ncRNAs during cardiac remodeling, involves them being secreted from some cells, and then being actively taken up by other target cells, thus contributing to cell-cell communications and paracrine signaling pathways [144-148].

\section{The role of ncRNAs in cardiac fibrosis}

The role of ncRNAs (especially miRNAs) has been shown in many studies [149-152]. The down-regulation of miR-122 has been reported in endomyocardial biopsies from patients with severe aortic valve stenosis (AS), compared to control subjects. Experiments in human fibroblasts have shown that miR-122 might be involved in myocardial fibrosis [153]. In one recent study, miR-34a was suggested to be a positive regulator of fibrogenesis. miR-34a was dynamically up-regulated following myocardial infarction, and inhibition of miR-34a resulted in decreased severity of cardiac fibrosis in mice. Functionally, miR-34a over-expression increased the profibrogenic activity. miR-22 is also involved in regulation of cardiac fibrosis. miR-22 was significantly reduced following myocardial infarction, leading to increased collagen deposition, thereby promoting cardiac fibrosis. Some ECM proteins, including Col1a1 and Col3a1, were overexpressed after miR-22 knock-down in cultured CFs. Another study demonstrated that miR-29 levels were decreased under cardiac stress, thereby increasing collagen expression and promoting cardiac fibrosis [154]. Overexpression of several lncRNAs, including n379599, n379519, n384648, n380433, and n410105, increased the expression of Col8A1, Col3A1, and FBN1 and increased cardiac fibrosis by inducing phosphorylation of Smad2/3 and TGF- $\beta$ signaling. Silencing of these IncRNAs induced the opposite effect [12]. The over-expression of 
Table 1 TGF $\beta$ and WNT signaling pathways involved in the regulation of cardiac fibrosis

\begin{tabular}{|c|c|c|c|c|}
\hline Pathway & Function & model & $\begin{array}{l}\text { Anti-fibrotic or } \\
\text { pro-fibrotic) }\end{array}$ & Reference \\
\hline Aldehyde dehydrogenase-2 (ALDH2) & $\begin{array}{l}\text { Decreased } \beta \text {-catenin, phosphorylated GSK-3 } \beta \text {, and } \\
\text { WNT-1 }\end{array}$ & $\mathrm{Ml} / \mathrm{rat}$ & Anti & [128] \\
\hline WNT10b & Increased Axin2, Lef1 and Tcf7 & $\begin{array}{l}\text { Transgenic (TG) } \\
\text { WNT10b mice }\end{array}$ & Anti & [129] \\
\hline S100A4 & Decreased $\beta$-catenin and phosphorylated $\beta$-catenin & LAD /mouse; CFs & Pro & [130] \\
\hline WNT3a and WNT5a & Decreased glycogen synthase kinase $3 \beta$ (GSK3 $\beta$ ) & Human CFs & Pro & [131] \\
\hline Qishen Granule (QSG) & $\begin{array}{l}\text { Inhibition of the TGF- } \beta / \text { Smad3 pathway and the } \\
\text { phosphorylation of GSK-3 } \beta\end{array}$ & HF/Rat & Anti & [132] \\
\hline Xinfuli Granule (XG) & Decreased Smad3, P-Smad3 and Smad2 protein & $\mathrm{Ml} / \mathrm{rat}$ & Anti & [133] \\
\hline Human antigen $\mathrm{R}$ (HuR) & Increased TGF- $\beta 1$ & $\begin{array}{l}\text { TAC/HuR-deletion } \\
\text { mouse }\end{array}$ & Pro & [134] \\
\hline $\begin{array}{l}\text { Transient receptor potential ankyrin } 1 \\
\text { (TRPA1) }\end{array}$ & Decreased TGF- $\beta$, IL-4 and IL-10 & TAC/mouse & Pro & [135] \\
\hline Small molecule inhibitor ICG-001 & Decreases $\beta$-Catenin & $\begin{array}{l}\text { Ang II infusion/ Cfs } \\
\text { Rat }\end{array}$ & Anti & [136] \\
\hline $\begin{array}{l}\text { EphrinB2 (erythropoietin-producing } \\
\text { hepatoma interactor B2) }\end{array}$ & Increased TGF- $\beta /$ Smad3 pathway and STAT3 & Ang II MI/ Mouse & Pro & [137] \\
\hline
\end{tabular}

miR-1954 showed a reduction in cardiac mass and blood pressure in mice. It also reduced expression of cardiac fibrotic genes, inflammatory genes, and hypertrophy marker genes. They found that miR-1954 played an important role in cardiac fibrosis by targeting THBS1, therefore it could be a promising strategy for the treatment of cardiac fibrosis [155].

CircRNAs are another type of single-stranded RNA molecules, which are involved in many normal physiological processes, as well as the pathogenesis of cardiovascular disease [156, 157]. For example, circHIPK3 affected the proliferation and migration of CFs, and the expression of genes such as COL1A1, COL3A1, $\alpha$-SMA through "sponging up" miR-29b-3p. Silencing of circHIPK3 showed opposite effects on CF proliferation, and the diastolic function was improved in vivo [158]. Microarray analysis of several circRNAs revealed a significant up-regulation of circRNA_010567 in a diabetic $\mathrm{db} / \mathrm{db}$ mouse model compared to controls. Knockdown of circRNA_010567 reduced the synthesis of fibrotic proteins, such as Col I, Col III and $\alpha$-SMA in CFs, which had been treated with Ang II [13]. ncRNAs could be attractive candidates as putative biomarkers for cardiac fibrosis in a variety of cardiovascular conditions, although their function needs to be fully investigated in future studies.

\section{Role of ncRNAs in TGF $\beta$ and/or WNT signaling}

The relationship between ncRNAs and TGF $\beta$ and/or WNT signaling has been demonstrated in studies, and could affect many pathogenic conditions. Colorectal cancer patients with high expression of certain lncRNAs had a shorter overall survival and a worse response to chemotherapy. It was found that these lncRNAs promoted CRC progression by activating Wnt/ $\beta$-catenin pathway through activator protein $2 \alpha$. Furthermore, lncRNA can induce multidrug resistance through activating Wnt/ $\beta$-catenin signaling by up-regulating MDR1/P-gp expression [159].

$\mathrm{Wu}$ et al. showed that down-regulation of IncRNA CCAT 2 reduced the expression of TGF- $\beta, \operatorname{Smad} 2$ and $\alpha-$ SMA in breast cancer patients. CCAT2 promoted growth and metastasis of breast cancer by regulating the TGF- $\beta$ signaling pathway [160].

Shan et al. found that over-expression of lncRNA Linc00675 inhibited the proliferation and migration of colorectal cancer cells. Furthermore, they found that the expression of miR-942 in clinical colorectal cancer tissues was higher than in normal tissue. More importantly, the inhibitory effect of Linc00675 was also attenuated by a miR-942 mimetic, suggesting that downregulation of miR-942 represented one of the mechanisms by which Linc00675 inhibited the proliferation and metastasis of colorectal cancer. They demonstrated the inhibition of $\mathrm{Wnt} / \beta$-catenin signaling in the Linc00675/miR-942 regulated pathway in colorectal cancer cells [161].

Yoan et al. found that over-expression of lncRNA CTD903 inhibited invasion and migration of colorectal cancer cells by repressing Wnt/ $\beta$-catenin signaling and predicts favorable prognosis [162]. LncTCF7 is a lncRNA which required for liver cancer stem cell self-renewal and tumor progression. $\operatorname{lncTCF7}$ recruited the SWI/SNF complex to the promoter of TCF7 to regulate its 
expression, leading to activation of Wnt signaling. lncTCF7-mediated Wnt signaling primes liver cancer stem cell self-renewal and tumor propagation [163].

In addition to lncRNAs, microRNAs have important roles in TGF $\beta$ and/or WNT signaling. Yu et al. found that microRNA-21 induces stemness by down-regulating TGF- $\beta$ receptor 2 (TGF $\beta R 2$ ) in colon cancer cells [164]. Tan et al. studied human orbital fibroblasts to show that TGF $\beta 1$ treatment decreased miR-29 expression, which could inhibit TGF $\beta 1$. MiR-29 inhibited TGF $\beta 1$-induced proliferation and decreased colony formation of orbital fibroblast cells after TGF $\beta 1$ treatment. MiR-29 mediates TGF $\beta 1$-induced extracellular matrix synthesis through activation of $\mathrm{Wnt} / \beta$-catenin pathway in human orbital fibroblasts [77].

In another study, salvianolic acid B (Sal B) treatment induced the inactivation of the Wnt/ $\beta$-catenin pathway, with an increase in phosphorylated- $\beta$-catenin and Wnt inhibitory factor 1 . It was found that miR-17-5p was reduced in vivo and in vitro after Sal B treatment. As confirmed by luciferase activity assays, WIF1 was a direct target of miR-17-5p. Importantly, the suppression of
HSCs induced by Sal B was almost completely inhibited by miR-17-5p mimetics. Therefore, miR-17-5p activates Wnt/ $\beta$-catenin pathway to result in HSC activation through inhibiting WIF1 expression [165].

\section{The relationship between ncRNAs and TGF $\beta$ and/ or WNT signaling in cardiac fibrosis}

Many studies have provided evidence for cross-talk between fibrosis development and miRNA deregulation, via the TGF $\beta$ and WNT signaling pathways (Fig. 2). Some of these studies are summarized in this section (Tables 2, 3 and 4).

For example, researchers found that TGF- $\beta 1$ and miR21 expression were up-regulated in the border zone of mouse heart after myocardial infarction, whereas TGF- $\beta$ receptor type III was down-regulated. TGF $\beta$ RIII is a negative regulator of the TGF- $\beta$ pathway. Overexpression of miR-21 attenuated TGF $\beta$ RIII expression in cardiac fibroblasts, thereby potentially contributing to excessive ECM production via the TGF- $\beta$ pathway [166]. However, using miR-21-knockout mice and knockdown of miR-21 expression, showed that cardiac fibrosis

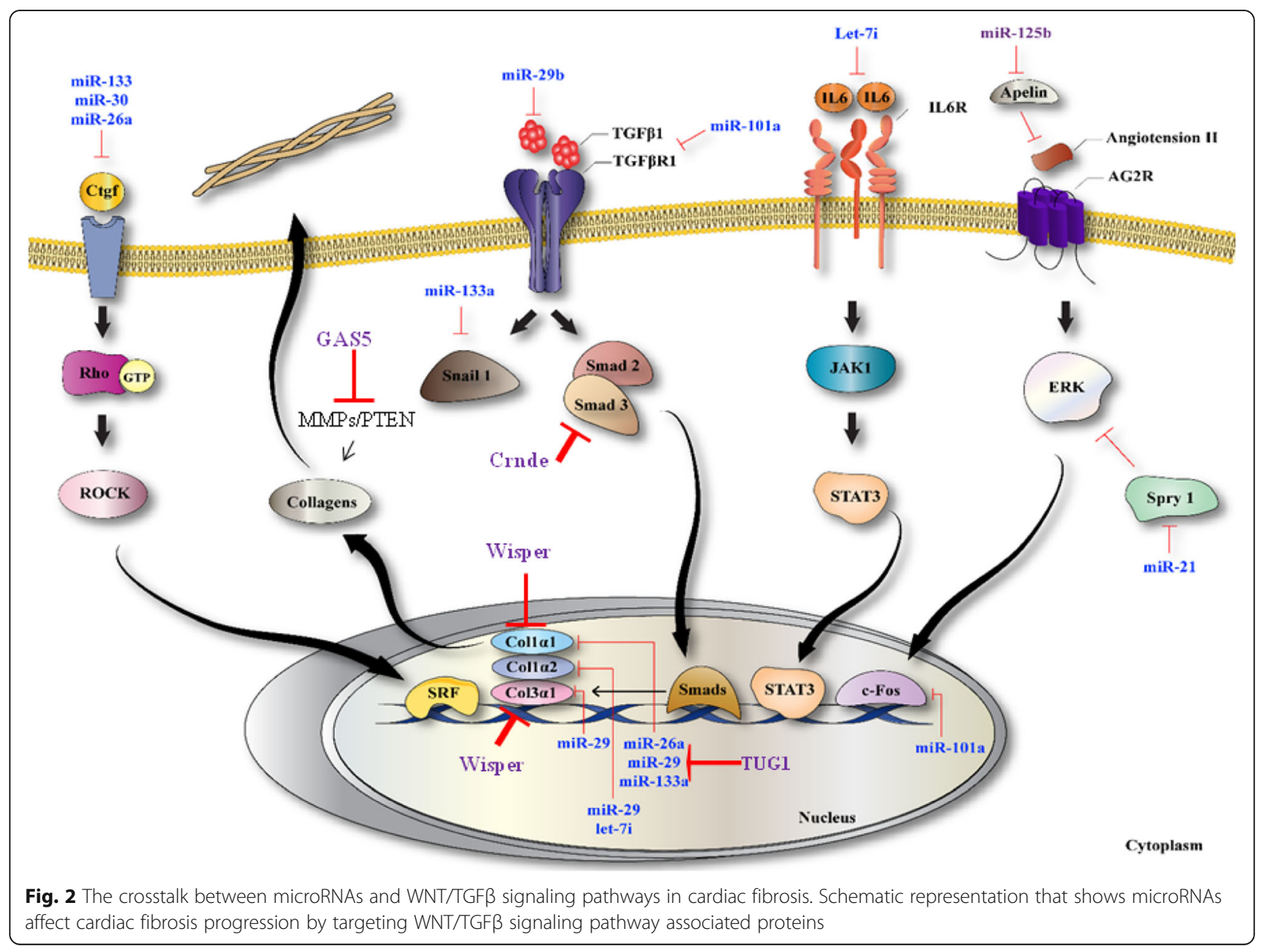


Table 2 miRNAs involved in the regulation of cardiac fibrosis mediated by TGF $\beta$ NWNT signaling pathways

\begin{tabular}{|c|c|c|c|c|c|}
\hline miRNAs & $\begin{array}{l}\text { Expression (up/ } \\
\text { down) }\end{array}$ & Function & model & $\begin{array}{l}\text { Anti- fibrotic Pro- } \\
\text { fibrotic }\end{array}$ & Reference \\
\hline miR-378 & Down & Activate RTK, GRB-2/TGF $\beta$ & Angll, TAC/mouse; CFs & Anti & [179] \\
\hline miR-101a & Down & $\begin{array}{l}\text { Suppress TGF } \beta \text { receptor I, } \\
\text { p-Smad3 }\end{array}$ & Ml, hypoxia/rat & Anti & [180] \\
\hline miR-145 & Up & Suppress TGF $\beta$ receptor II & $\begin{array}{l}\text { Smooth muscle cells; } \\
\text { Ang II/mouse }\end{array}$ & Anti & [181] \\
\hline miR-675 & Down & Suppress TGF $\beta$ receptor I & TGFb /mouse CFs & Anti & [182] \\
\hline miR-10a & Up & Activate TGF- $\beta 1 /$ Smads signaling pathway & Rat CFs & Pro & [183] \\
\hline miR-15 & Up & $\begin{array}{l}\text { Suppress TGF } \beta \text { receptor I, p38, endoglin, } \\
\text { Smad3/7 }\end{array}$ & TAC/mouse & Anti & [184] \\
\hline miR-9 & Down & Suppress TGF $\beta$ receptor II & High glucose/human CFs & Anti & [185] \\
\hline miR-223 & Up & $\begin{array}{l}\text { Suppress RASA1 /Activate RAS and smad } \\
\text { signaling pathways }\end{array}$ & $\mathrm{Ml} /$ Rat CFs & Pro & [186] \\
\hline $\begin{array}{l}\text { MiR- } \\
\text { 323a-3p }\end{array}$ & Up & Suppress TIMP3/ActivateTGF- $\beta$ pathway & Angll, TAC/mouse; CFs & Pro & [187] \\
\hline $\begin{array}{l}\operatorname{miR}-202- \\
3 p\end{array}$ & Down & Suppress TRPM6, TGF $\beta 1$, Smad 2 and $p-S m a d 2$ & $\begin{array}{l}\text { Rat myocardial ischemic-reperfusion } \\
\text { (I/R) injury }\end{array}$ & Anti & [188] \\
\hline miR-433 & Up & Activate TGF $\beta 1$, ERK, p38 kinase and Smad3 & Ml/mice & Pro & [189] \\
\hline miR-29b & Down & Suppress Smad3 signaling & Ml/Rat & Anti & [190] \\
\hline miR-495 & Down & $\begin{array}{l}\text { Suppress NOD1, NF-KB and TGF } \beta 1 / \text { Smad signal- } \\
\text { ing pathways }\end{array}$ & High glucose/human CFs & Anti & [191] \\
\hline miR-154 & Up & Suppress GSK-3ß/ Activate WNT signaling & Human CFs & Pro & [192] \\
\hline miR-154 & Up & Suppress DKK2/ Activate WNT signaling & Human CFs & Pro & [193] \\
\hline miR-199a & Up & $\begin{array}{l}\text { Suppress secreted frizzled-related protein } 5 \\
\text { (SFRP5) }\end{array}$ & ISO, Rat CFs & Pro & [194] \\
\hline miR-503 & Up & $\begin{array}{l}\text { Activate connective tissue growth factor (CTGF) } \\
\text { and TGF- } \beta\end{array}$ & Angll, TAC/mouse; CFs & Pro & [195] \\
\hline
\end{tabular}

could still develop under conditions of cardiac stress. These data suggested that miR-21 was not essential for pathological cardiac remodeling [167]. In animal models of myocardial infarction, miR-101 is usually repressed, and delivery of miR-101 by an adeno-associated virus led to amelioration of the infarcted heart through activation of the proto-oncogene c-fos and silencing of the TGF $\beta 1$ pathway [168]. miR-133a was down-regulated in a model of atrial fibrillation in dogs, induced by administration of nicotine. Over-expression of miR-133a decreased TGF- $\beta 1$ and levels of TGF- $\beta$ receptor type II, and also reduced the collagen content in cultured atrial fibroblasts [169]. AS mentioned above, miR-34a overexpression increased the pro-fibrogenic activity, whereas miR-34a inhibition reduced the activity of TGF- $\beta 1$ by directly targeting Smad4 in CF cells [11]. Furthermore, it is suggested that direct down-regulation of TGF $\beta$ by miR-22 may have mediated the anti-fibrotic effect. miR29 may also play a role in the regulation of cardiac fibrosis. In a mouse model of aortic aneurysm, inhibition of

Table 3 LncRNAs involved in the regulation of cardiac fibrosis mediated by TGF $\beta /$ WNT signaling pathways

\begin{tabular}{|c|c|c|c|c|c|}
\hline LncRNAs & $\begin{array}{l}\text { Expression } \\
\text { (up/down) }\end{array}$ & Function & Model & $\begin{array}{l}\text { Anti- fibrotic } \\
\text { or Pro-fibrotic }\end{array}$ & Reference \\
\hline n379519 & Up & $\begin{array}{l}\text { Sponged miR-30/Activated TGF } \beta \text { signaling } \\
\text { pathway }\end{array}$ & $\begin{array}{l}\text { TGF } \beta \\
\text { MI/ Rat CFs }\end{array}$ & Pro & [196] \\
\hline $\begin{array}{l}\text { Taurine Upregulated Gene } 1 \\
\text { (TUG1) }\end{array}$ & Up & $\begin{array}{l}\text { Sponged miR-29c/Activated TGF } \beta \text { signaling } \\
\text { pathway }\end{array}$ & $\begin{array}{l}\text { Congenital human heart } \\
\text { tissue, chronic hypoxic mouse } \\
\text { CFs }\end{array}$ & Pro & [197] \\
\hline $\begin{array}{l}\text { Homeobox A11 antisense } \\
\text { (HOXA11-AS) }\end{array}$ & Up & Activated TGF $\beta$ signaling pathway & Mouse CFs & Pro & [198] \\
\hline $\begin{array}{l}\text { Colorectal neoplasia } \\
\text { differentially expressed } \\
\text { (Crnde) }\end{array}$ & Down & $\begin{array}{l}\text { Inhibited the binding of Smad3 to the a- } \\
\text { SMA gene promoter via interacting with } \\
\text { rSBEs }\end{array}$ & DCM/Human, mouse/CFs & Anti & [199] \\
\hline
\end{tabular}


Table 4 Circular RNAs involved in the regulation of cardiac fibrosis mediated by TGF $\beta$ NNT signaling pathways

\begin{tabular}{|c|c|c|c|c|c|}
\hline CircRNAs & $\begin{array}{l}\text { Expression (up/ } \\
\text { down) }\end{array}$ & Function & model & $\begin{array}{l}\text { Anti- fibrotic } \\
\text { Pro-fibrotic }\end{array}$ & Reference \\
\hline $\begin{array}{l}\text { circRNA_ } \\
010567\end{array}$ & Up & $\begin{array}{l}\text { Regulated TGF- } \beta \text { signaling and ECM synthesis via sponging } \\
\text { up miR-141 }\end{array}$ & $\begin{array}{l}\text { Diabetic mice } \\
\text { myocardium and CFs }\end{array}$ & Pro & [178] \\
\hline CircACTA2 & Up & $\begin{array}{l}\text { Regulated the expression and function of a-SMA, by acting as } \\
\text { a decoy for miR- } 548 f-5 p \text {. } \\
\text { TGF- } \beta \text { over-expression increased circACTA2. }\end{array}$ & $\begin{array}{l}\text { Rat, mouse, and human } \\
\text { VSMCs }\end{array}$ & Pro & [13] \\
\hline
\end{tabular}

miR-29 led to greater stability in the aortic walls, and prevented rupture by increasing the expression of several ECM genes, such as Col1A1, Col3A1, and elastin [170]. It is indicated that TGF $\beta$ could repress miR-29 expression under cardiac stress [154]. Suppression of miR-155 reduced infarct size, improved LV function, and attenuated collagen deposition in vivo. Knockout of miR-155 arrested the proliferation of CFs and their differentiation into myofibroblasts, through up-regulation of "tumor protein p53-inducible nuclear protein1" (TP53INP1) [171]. TP53INP1 is a pro-apoptotic protein that can interact with p53 and modulate p53 transcriptional activity [172]. A previous report showed that TGF- $\beta$ could indirectly regulate TP53INP1 expression by affecting miR-155 levels in liver cancer cells [173]. miR-24 also plays a role in the regulation of myocardial infarctioninduced cardiac fibrosis, possibly through targeting furin [174]. Furin is a protease related to the TGF- $\beta$ pathway, and has been reported to regulate production of collagen in fibrosis [175]. A different study revealed that upregulation of a LncRNA, also known as "myocardial infarction associated transcript" (MIAT), in myocardial infarction was accompanied by down-regulation of miR-24 and up-regulation of Furin and TGF- $\beta 1$ [176]. One lncRNA, known as HOTAIR (HOX transcript antisense RNA) was associated with myocardial fibrosis via activation of the WNT signaling pathway through targeting the URI1 gene (unconventional prefoldin RPB5 interactor 1). HOTAIR over-expression elevated the expression of axin $2, \beta$-catenin and p-GSK-3 $\beta$, and also promoted cell proliferation and migration in CFs. Results showed that the regulatory effects of HOTAIR over-expression on CF functions were the same as those found after URI1 over-expression, suggesting that HOTAIR may regulate CFs by targeting URI1 [12].

Seo et al. showed that miR-384-5p was a key mediator in the formation of a transactivation circuit between the TGF- $\beta$ and WNT signaling pathways in cardiac fibrosis. This function might be related to the modulation of different receptors, such as Fzd1, Fzd2, TGF $\beta R 1$, and LRP6. The expression of miR-384-5p was significantly decreased in CFs at 3 and 7 days after ischemia/reperfusion (I/R) injury, and $24 \mathrm{~h}$ after TGF- $\beta$ treatment. Moreover, the over-expression of miR-384-5p significantly attenuated cardiac fibrosis and decreased the fibrotic area in the rat $I / R$ injury model. These findings suggested that miR-384-5p might be able to control cardiac fibrosis [177]. A recent study reported that inhibition of miR-27a exhibited a cardio-protective effect by regulating the WNT and TGF- $\beta$ pathways, through modulating the expression of the $\beta$-catenin, $\mathrm{p}-$ GSK-3 $\beta$ and $\alpha$-SMA genes. According to this investigation, miR-27a levels were increased in the fibrotic heart tissue of rats with chronic heart failure (CHF), and the data suggested that miR-27a might be a target for treating cardiac fibrosis [17]. Furthermore, circRNA_010567 regulated TGF- $\beta$ signaling and ECM synthesis via sponging up miR-141 [178]. Moreover, it has been reported that CircActa2 was involved in myocardial and endocardial fibrosis, through regulation of the expression and function of $\alpha$ SMA, by acting as a decoy for miR-548f-5p. It was shown that TGF- $\beta$ over-expression increased circACTA2, thereby facilitating the formation of stress fibers and cell contraction [13].

\section{Conclusions}

The relentless progression of fibrosis is well known to be a pathological finding in many cardiac conditions. The mechanisms responsible for this process are rather complex, and involve multiple pathways. Therefore, a better understanding of the functional characteristics and molecular profiles of these fibrotic processes could provide solutions for the prevention and treatment of fibrotic lesions in the heart. Accumulating evidence points to the cross-talk between the TGF- $\beta$ and WNT signaling pathways in the pathogenesis of cardiac fibrosis. Although the cell biology of the TGF- $\beta$ and WNT pathways has been well-described in cellular development and in the pathophysiology of many diseases, the mechanisms of these pro-fibrotic pathways in cardiac pathologies is less well-understood. As discussed in this review, canonical WNT signaling and TGF- $\beta$ signaling can combine together to regulate fibrotic processes in the heart, and is likely to play a key role in switching on the genetic machinery for the pro-fibrotic changes. ncRNAs have increasingly been recognized to play possible roles in strategies for combating CVDs, as described above. Recent studies in the ncRNA field that are described in this review, also indicate the important function of ncRNAs in the regulation of cell signaling pathways, 
especially TGFB and WNT signaling. Information gathered from these experiments, and identification of the signaling pathways of the ncRNAs involved with cardiac fibrosis, may lead to a new target for treatment strategies for cardiac fibrosis. Additional research is needed to identify the exact details of the mechanism by which the ncRNA network affects cardiac fibrosis through TGF $\beta$ / WNT signaling. Moreover, the possible clinical importance of these TGF $\beta /$ WNT related ncRNAs, such as the use of microRNAs as therapeutic tools, and circRNAs as diagnostic/prognostic biomarkers for cardiac fibrosis should be examined in additional animal and clinical trials.

\section{Abbreviations}

ACE2: Angiotensin-Converting Enzyme 2; ACTA2: Smooth muscle alpha (a)-2 actin; ADAM17: A disintegrin and metalloproteinase 17; ALDH2: Aldehyde dehydrogenase-2; Angll: Angiotensin II; AP-1: Activator protein 1;

APC: Adenomatous polyposis coli; ATFs: Activating transcription factors; CAMP: response element modulator; CBP: CREB binding protein; CFs: Cardiac fibroblasts; CHF: Chronic heart failure; ChIP: Chromatin immunoprecipitation; CircHIPK3: Circular RNA Homeodomain Interacting Protein Kinase 3; circRNAs: Circular long noncoding RNAs; CK1: Casein kinase 1; CMR: Cardiac magnetic resonance; Crnde: Colorectal neoplasia differentially expressed; CTGF: Connective tissue growth factor; DCM: Dilated cardiomyopathy; DKK: Dikkopf; sFRP: Secreted frizzled-related protein; DVL: Dishevelled;: ECM: Extracellular matrix; ED-A: Extra domain A; Erk1/2: Extracellular signalregulated kinase 1 and 2; FGF 23: Fibroblast growth factor 23; Fz: Frizzled; LRP: Low-density-lipoprotein-receptor-related proteins; GRB-2: Growth factor

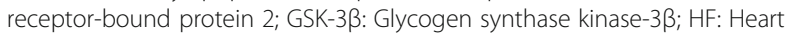
failure; HOTAIR: HOX transcript antisense RNA; HOXA11-AS: Homeobox A11 antisense; HuR: Human antigen R; I/R: Ischemic-reperfusion (I/R) injury; ISmad: Inhibitory Smad; ISO: Isoproterenol; SFRP5: Secreted frizzled-related protein 5; JNK: Jun N-terminal kinase; JNKs: c-Jun N-terminal kinases; LAP: Latency-associated protein; IncRNAs: Long noncoding RNAs; LTBPS: Latent TGF- $\beta$-binding proteins; LV: Left ventricle; MAPK: MitogenActivated Protein Kinase; MI: Myocardial infarction; MIAT: Myocardial infarction associated transcript; MiRNAs: MicroRNAs; mTOR: Mammalian target of rapamycin; ncRNAs: non-coding RNAs; NF-Kb: Nuclear factor kappalight-chain-enhancer of activated B cells; NOD1: Nucleotide-binding oligomerization domain-containing protein 1; PAl: Plasminogen activator inhibitor; PI3K/Akt: Phosphatidylinositol 3-kinase/ Protein Kinase B; PKC: Protein kinase C; QSG: Qishen Granule; RAS: Renin-angiotensin system; ROCK: Rho-associated protein kinase; RSBEs: RNA Smad-binding elements; RTK: Receptor tyrosine kinase; SIRT3: Sirtuin 3 a-SMA Alpha-smooth muscle actin; STAT3: Signal Transducer and Activator of Transcription 3; TAC: Transverse aorta constriction; TAC:EphrinB2: Erythropoietin-producing hepatoma interactor B2; TCF/Lef-1: T-cell factor/lymphoid enhancer-binding factor-1; TG: Transgenic; LAD: Left anterior descending; TGF- $\beta$

R1: Transforming growth factor beta receptor 1 ; TGF- $\beta$ : Transforming growth factor beta; TIMP3: Tissue inhibitor of matrix metalloproteinases-3; TIMPs: Tissue inhibitor of metalloproteinases; TP53INP1: Tumor protein p53inducible nuclear protein 1; TRPA1: Transient receptor potential ankyrin 1; TUG1: Taurine Upregulated Gene 1; URI1: Unconventional prefoldin RPB5 interactor 1; WNT: Wingless-related integration site; XG: Xinfuli Granule

\section{Acknowledgements}

Not applicable.

\section{Authors' contributions}

$\mathrm{HM}, \mathrm{AS}$ and $\mathrm{MRH}$ contributed in conception, design, statistical analysis and drafting of the manuscript. FGH, ZS, SV, MD, AN, MMT, HD, AM, and YGH contributed in conception, data collection and manuscript drafting. $\mathrm{HM}$ and MMT contributed in revised version. The final version was confirmed by all authors for submission. The author(s) read and approved the final manuscript.

\section{Funding}

MRH was supported by US NIH Grants R01Al050875 and R21Al121700.

\section{Availability of data and materials}

The primary data for this study is available from the authors on direct request.

\section{Ethics approval and consent to participate}

This study was considered exempt by the KAUMS Institutional Review Board.

\section{Consent for publication}

Not applicable.

\section{Competing interests}

$\mathrm{MRH}$ declares the following potential conflicts of interest. Scientific Advisory Boards: Transdermal Cap Inc., Cleveland, OH; BeWell Global Inc., Wan Chai, Hong Kong; Hologenix Inc. Santa Monica, CA; LumiThera Inc., Poulsbo, WA; Vielight, Toronto, Canada; Bright Photomedicine, Sao Paulo, Brazil; Quantum Dynamics LLC, Cambridge, MA; Global Photon Inc., Bee Cave, TX; Medical Coherence, Boston MA; NeuroThera, Newark DE; JOOW Inc., Minneapolis-St. Paul MN; AIRx Medical, Pleasanton CA; FIR Industries, Inc. Ramsey, NJ; UVLRx Therapeutics, Oldsmar, FL; Ultralux UV Inc., Lansing Ml; Illumiheal \& Petthera, Shoreline, WA; MB Lasertherapy, Houston, TX; ARRC LED, San Clemente, CA; Varuna Biomedical Corp. Incline Village, NV; Niraxx Light Therapeutics, Inc., Boston, MA. Consulting; Lexington Int, Boca Raton, FL; USHIO Corp, Japan; Merck KGaA, Darmstadt, Germany; Philips Electronics Nederland B.V. Eindhoven, Netherlands; Johnson \& Johnson Inc., Philadelphia, PA; Sanofi-Aventis Deutschland GmbH, Frankfurt am Main, Germany. Stockholdings: Global Photon Inc., Bee Cave, TX; Mitonix, Newark, DE. Other authors declare no conflict of interest.

\section{Author details}

${ }^{1}$ Department of Genetics, Faculty of Biological Sciences, Tarbiat Modares University, Tehran, Iran. ${ }^{2}$ Department of Nanotechnology, Faculty of Biological Sciences, Tarbiat Modares University, Tehran, Iran. ${ }^{3}$ Pharmaceutical Sciences Research Center, Shiraz University of Medical Sciences, Shiraz, Iran. ${ }^{4}$ Biochemistry Department, Medical School, Shiraz University of Medical Sciences, Shiraz, Iran. ${ }^{5}$ Department of Pathology, Isfahan University of Medical Sciences, Isfahan, Iran. ${ }^{6}$ Department of Medical Biotechnology, School of Advanced Medical Sciences and Technologies, Shiraz University of Medical Sciences, Shiraz, Iran. 7 Student research committee, Shiraz University of Medical Sciences, Shiraz, Iran. ${ }^{8}$ Department of Stem Cell and Development Biology, Cell Science Research Center, Royan Institute for Stem Cell Biology and Technology, ACECR, Tehran, Iran. ${ }^{9}$ Department of Pharmaceutical Biotechnology, School of Pharmacy and Pharmaceutical Sciences Research Center, Shiraz University of Medical Sciences, Shiraz, Iran. ${ }^{10}$ Student Research Committee, Mashhad University of Medical Sciences, Mashhad, Iran.

${ }^{11}$ Department of Medical Biotechnology, Faculty of Medicine, Mashhad University of Medical Sciences, Mashhad, Iran. ${ }^{12}$ Pathology Department, School of Medicine,Mashhad Univesity of Medical Sciences, Mashhad, Iran.

${ }^{13}$ Research Center for Biochemistry and Nutrition in Metabolic Diseases, Institute for Basic Sciences, Kashan University of Medical Sciences, Kashan, IR, Iran. ${ }^{14}$ Wellman Center for Photomedicine, Massachusetts General Hospital, Harvard Medical School, 40 Blossom Street, Boston, MA 02114, USA. ${ }^{15}$ Laser Research Centre, Faculty of Health Science, University of Johannesburg, Doornfontein 2028, South Africa.

Received: 2 January 2020 Accepted: 17 March 2020

Published online: 09 June 2020

\section{References}

1. Asbun J, Villarreal FJ. The pathogenesis of myocardial fibrosis in the setting of diabetic cardiomyopathy. J Am Coll Cardiol. 2006;47:693-700.

2. Kong P, Christia P, Frangogiannis NG. The pathogenesis of cardiac fibrosis Cell Mol Life Sci. 2014;71:549-74.

3. Bharati S, Lev M. Cardiac conduction system involvement in sudden death of obese young people. Am Heart J. 1995;129:273-81.

4. Weber KT, Sun Y, Bhattacharya SK, Ahokas RA, Gerling IC. Myofibroblastmediated mechanisms of pathological remodelling of the heart. Nat Rev Cardiol. 2013;10:15. 
5. van den Borne SW, Isobe S, Verjans JW, Petrov A, Lovhaug D, Li P, Zandbergen $\mathrm{HR}$, Ni Y, Frederik P, Zhou J. Molecular imaging of interstitial alterations in remodeling myocardium after myocardial infarction. J Am Coll Cardiol. 2008:52:2017-28.

6. Akhmetshina A, Palumbo K, Dees C, Bergmann C, Venalis P, Zerr P, Horn A, Kireva T, Beyer C, Zwerina J. Activation of canonical Wnt signalling is required for TGF- $\beta$-mediated fibrosis. Nat Commun. 2012;3:735.

7. Villarreal FJ, Dillmann WH. Cardiac hypertrophy-induced changes in mRNA levels for TGF-beta 1, fibronectin, and collagen. Am J Physiol Heart Circ Physiol. 1992;262:H1861-6.

8. Piersma B, Bank RA, Boersema M. Signaling in fibrosis: TGF- $\beta$, WNT, and YAP/TAZ converge. Front Med. 2015;2:59.

9. Esteller M. Non-coding RNAs in human disease. Nat Rev Genet. 2011;12:861.

10. Rezaeian AH, Khanbabaei H: Therapeutic Potential of the miRNA-ATM Axis in the Management of Tumor Radioresistance. Cancer Res. 2020;80(2):13950.

11. Huang Y, Qi Y, Du J-Q, Zhang D-F: MicroRNA-34a regulates cardiac fibrosis after myocardial infarction by targeting Smad4. Expert Opin Ther Targets 2014, 18:1355-1365.

12. Pan S, Cui H, Qiu C. HOTAIR promotes myocardial fibrosis through regulating URI1 expression via Wnt pathway. Eur Rev Med Pharmacol Sci. 2018;22:6983-90.

13. Sun $Y$, Yang Z, Zheng B, Zhang X-H, Zhang M-I, Zhao X-S, Zhao H-Y, Suzuki T, Wen J-K: A novel regulatory mechanism of smooth muscle a-actin expression by NRG-1/circACTA2/miR-548f-5p axis. Circ Res 2017, 121:628-635.

14. Carthy JM, Garmaroudi FS, Luo Z, McManus BM. Wnt3a induces myofibroblast differentiation by upregulating TGF- $\beta$ signaling through SMAD2 in a $\beta$-catenin-dependent manner. PLoS One. 2011;6:e19809.

15. Hao H, Li X, Li Q, Lin H, Chen Z, Xie J, Xuan W, Liao W, Bin J, Huang X. FGF23 promotes myocardial fibrosis in mice through activation of $\beta$-catenin. Oncotarget. 2016;7:64649.

16. Działo E, Tkacz K, Błyszczuk P. Crosstalk between TGF- $\beta$ and WNT signalling pathways during cardiac fibrogenesis. Acta Biochim Pol. 2018;65:341-9.

17. Zhuang Y, Liao Y, Liu B, Fang Z, Chen L, Min L, Chen W. MicroRNA-27a mediates the Wnt/ $\beta$-catenin pathway to affect the myocardial fibrosis in rats with chronic heart failure. Cardiovasc Ther. Cardiovasc Ther. 2018; e12468

18. Hao J, Ju H, Zhao S, Junaid A, Scammell-La Fleur T, Dixon IM. Elevation of expression of Smads 2, 3, and 4, decorin and TGF- $\beta$ in the chronic phase of myocardial infarct scar healing. J Mol Cell Cardiol. 1999;31:667-78.

19. Vilahur G, Juan-Babot O, Peña E, Oñate B, Casaní L, Badimon L. Molecular and cellular mechanisms involved in cardiac remodeling after acute myocardial infarction. J Mol Cell Cardiol. 2011;50:522-33.

20. Wünsch M, Sharma H, Markert T, Bernotat-Danielowski S, Schott R, Kremer $P$ Bleese $N$, Schaper W. In situ localization of transforming growth factor $\beta 1$ in porcine heart: enhanced expression after chronic coronary artery constriction. J Mol Cell Cardiol. 1991;23:1051-62.

21. Bujak M, Frangogiannis NG. The role of TGF- $\beta$ signaling in myocardial infarction and cardiac remodeling. Cardiovasc Res. 2007;74:184-95.

22. Deten A, Hölzl A, Leicht M, Barth W, Zimmer H-G. Changes in extracellular matrix and in transforming growth factor beta isoforms after coronary artery ligation in rats. J Mol Cell Cardiol. 2001;33:1191-207.

23. Thompson NL, Flanders KC, Smith JM, Ellingsworth LR, Roberts $A B$, Sporn MB. Expression of transforming growth factor-beta 1 in specific cells and tissues of adult and neonatal mice. J Cell Biol. 1989;108:661-9.

24. Morikawa M, Derynck R, Miyazono K. TGF- $\beta$ and the TGF- $\beta$ family: contextdependent roles in cell and tissue physiology. Cold Spring Harb Perspect Biol. 2016;8:a021873.

25. Cox DA. Transforming growth factor-beta 3. Cell Biol Int. 1995;19:357-72.

26. Fuji D, Brissenden JE, Derynck R, Francke U. Transforming growth factor $\beta$ gene maps to human chromosome 19 long arm and to mouse chromosome 7. Somat Cell Mol Genet. 1986;12:281-8.

27. Barton D, Foellmer B, Du J, Tamm J, Derynck R, Francke U. Chromosomal mapping of genes for transforming growth factors beta 2 and beta 3 in man and mouse: dispersion of TGF-beta gene family. Oncogene Res. 1988;3: 323-31

28. Dickson MC, Martin JS, Cousins FM, Kulkarni AB, Karlsson S, Akhurst RJ. Defective haematopoiesis and vasculogenesis in transforming growth factor-beta 1 knock out mice. Development. 1995;121:1845-54.

29. Kulkarni AB, Huh C-G, Becker D, Geiser A, Lyght M, Flanders KC, Roberts AB, Sporn MB, Ward JM, Karlsson S. Transforming growth factor beta 1 null mutation in mice causes excessive inflammatory response and early death. Proc Natl Acad Sci. 1993;90:770-4.

30. Proetzel G, Pawlowski SA, Wiles MV, Yin M, Boivin GP, Howles PN, Ding J, Ferguson MW, Doetschman T. Transforming growth factor- $\beta 3$ is required for secondary palate fusion. Nat Genet. 1995;11:409.

31. Sanford LP, Ormsby I, Gittenberger-de Groot AC, Sariola H, Friedman R, Boivin GP, Cardell EL, Doetschman T. TGFbeta2 knockout mice have multiple developmental defects that are non-overlapping with other TGFbeta knockout phenotypes. Development. 1997;124:2659-70.

32. Oida T, Weiner HL. Overexpression of TGF- $\beta 1$ gene induces cell surface localized glucose-regulated protein 78-associated latency-associated peptide/TGF-ß. J Immunol. 2010;185:3529-35.

33. Jenkins RG, Su X, Su G, Scotton CJ, Camerer E, Laurent GJ, Davis GE, Chambers RC, Matthay MA, Sheppard D. Ligation of protease-activated receptor 1 enhances a $\vee \beta 6$ integrin-dependent TGF- $\beta$ activation and promotes acute lung injury. J Clin Invest. 2006;116:1606-14.

34. Annes JP, Chen Y, Munger JS, Rifkin DB. Integrin aVB6-mediated activation of latent TGF- $\beta$ requires the latent TGF- $\beta$ binding protein-1. J Cell Biol. 2004; 165:723-34.

35. Roberts $A B$. TGF- $\beta$ signaling from receptors to the nucleus. Microbes Infect. 1999;1:1265-73.

36. Attisano L, Wrana JL. Signal transduction by the TGF- $\beta$ superfamily. Science. 2002;296:1646-7.

37. Verrecchia F, Mauviel A. Transforming growth factor- $\beta$ signaling through the Smad pathway: role in extracellular matrix gene expression and regulation. J Investig Dermatol. 2002;118:211-5.

38. Liu B, Dou C-L, Prabhu L, Lai E. FAST-2 is a mammalian winged-helix protein which mediates transforming growth factor $\beta$ signals. Mol Cell Biol. 1999;19: 424-30.

39. Shen X, Hu PP-C, Liberati NT, Datto MB, Frederick JP, Wang X-F. TGF- $\beta$ induced phosphorylation of Smad3 regulates its interaction with coactivator p300/CREB-binding protein. Mol Biol Cell. 1998;9:3309-19.

40. Yang Y-C, Piek E, Zavadil J, Liang D, Xie D, Heyer J, Pavlidis P, Kucherlapati R, Roberts $A B$, Böttinger EP. Hierarchical model of gene regulation by transforming growth factor $\beta$. Proc Natl Acad Sci. 2003;100:10269-74.

41. Nomura M, Li E. Smad2 role in mesoderm formation, left-right patterning and craniofacial development. Nature. 1998;393:786.

42. Nakao A, Afrakhte M, Morn A, Nakayama T, Christian JL, Heuchel R, Itoh S, Kawabata M, Heldin N-E, Heldin C-H. Identification of Smad7, a TGF $\beta$ inducible antagonist of TGF- $\beta$ signalling. Nature. 1997;389:631.

43. Fukuchi M, Imamura T, Chiba T, Ebisawa T, Kawabata M, Tanaka K, Miyazono K. Ligand-dependent degradation of Smad3 by a ubiquitin ligase complex of ROC1 and associated proteins. Mol Biol Cell. 2001;12:1431-43.

44. Wang T. The 265 proteasome system in the signaling pathways of TGF-beta superfamily. Front Biosci. 2003;8:d1109-27.

45. Oudit GY, Sun H, Kerfant B-G, Crackower MA, Penninger JM, Backx PH. The role of phosphoinositide-3 kinase and PTEN in cardiovascular physiology and disease. J Mol Cell Cardiol. 2004;37:449-71.

46. Zhang YE. Non-Smad pathways in TGF- $\beta$ signaling. Cell Res. 2009;19:128

47. Heasman SJ, Ridley AJ. Mammalian rho GTPases: new insights into their functions from in vivo studies. Nat Rev Mol Cell Biol. 2008:9:690.

48. Haudek SB, Gupta D, Dewald O, Schwartz RJ, Wei L, Trial J, Entman ML. Rho kinase-1 mediates cardiac fibrosis by regulating fibroblast precursor cell differentiation. Cardiovasc Res. 2009;83:511-8.

49. Zhang Y-M, Bo J, Taffet GE, Chang J, Shi J, Reddy AK, Michael LH, Schneider MD, Entman ML, Schwartz RJ. Targeted deletion of ROCK1 protects the heart against pressure overload by inhibiting reactive fibrosis. FASEB J. 2006; 20:916-25.

50. Molina-Pinelo S, Suárez R, Pastor MD, Nogal A, Márquez-Martín E, MartínJuan J, Carnero A, Paz-Ares L. Association between the miRNA signatures in plasma and bronchoalveolar fluid in respiratory pathologies. Dis Markers. 2012:32:221-30

51. Petrich BG, Wang Y. Stress-activated MAP kinases in cardiac remodeling and heart failure: new insights from transgenic studies. Trends Cardiovasc Med. 2004;14:50-5.

52. Engel ME, McDonnell MA, Law BK, Moses HL. Interdependent SMAD and JNK signaling in transforming growth factor- $\beta$-mediated transcription. J Biol Chem. 1999:274:37413-20.

53. Luo J, Chen J, Deng Z-L, Luo X, Song W-X, Sharff KA, Tang N, Haydon RC, Luu HH, He T-C. Wnt signaling and human diseases: what are the therapeutic implications? Lab Invest. 2007;87:97. 
54. Moon RT, Kohn AD, De Ferrari GV, Kaykas A. WNT and $\beta$-catenin signalling: diseases and therapies. Nat Rev Genet. 2004;5:691.

55. van de Schans VA, Smits JF, Blankesteijn WM. The Wnt/frizzled pathway in cardiovascular development and disease: friend or foe? Eur J Pharmacol. 2008:585:338-45.

56. Clevers H, Nusse R. Wnt/ $\beta$-catenin signaling and disease. Cell. 2012;149: 1192-205.

57. Kusserow A, Pang K, Sturm C, Hrouda M, Lentfer J, Schmidt HA, Technau U, Von Haeseler A, Hobmayer B, Martindale MQ. Unexpected complexity of the Wnt gene family in a sea anemone. Nature. 2005:433:156.

58. van Amerongen R, Mikels A, Nusse R. Alternative wnt signaling is initiated by distinct receptors. Sci Signal. 2008;1:re9.

59. Zeng X, Tamai K, Doble B, Li S, Huang H, Habas R, Okamura H, Woodgett J, He X. A dual-kinase mechanism for Wnt co-receptor phosphorylation and activation. Nature. 2005:438:873.

60. Liu C, Li Y, Semenov M, Han C, Baeg G-H, Tan Y, Zhang Z, Lin X, He X. Control of $\beta$-catenin phosphorylation/degradation by a dual-kinase mechanism. Cell. 2002;108:837-47.

61. Davidson G, Wu W, Shen J, Bilic J, Fenger U, Stannek P, Glinka A, Niehrs C. Casein kinase 1 y couples Wnt receptor activation to cytoplasmic signal transduction. Nature. 2005;438:867.

62. Bilić J, Huang Y-L, Davidson G, Zimmermann T, Cruciat C-M, Bienz M, Niehrs C. Wnt induces LRP6 signalosomes and promotes dishevelled-dependent LRP6 phosphorylation. Science. 2007;316:1619-22.

63. Taelman VF, Dobrowolski R, Plouhinec J-L, Fuentealba LC, Vorwald PP, Gumper I, Sabatini DD, De Robertis EM. Wnt signaling requires sequestration of glycogen synthase kinase 3 inside multivesicular endosomes. Cell. 2010;143:1136-48.

64. Bergmann MW. WNT signaling in adult cardiac hypertrophy and remodeling: lessons learned from cardiac development. Circ Res. 2010;107:1 198-208.

65. Rao TP, Kühl M. An updated overview on Wnt signaling pathways: a prelude for more. Circ Res. 2010;106:1798-806.

66. Schlessinger K, Hall A, Tolwinski N. Wnt signaling pathways meet rho GTPases. Genes Dev. 2009;23:265-77.

67. Beyer C, Schramm A, Akhmetshina A, Dees C, Kireva T, Gelse K, Sonnylal S, de Crombrugghe $B$, Taketo MM, Distler $O$. $\beta$-catenin is a central mediator of profibrotic Wnt signaling in systemic sclerosis. Ann Rheum Dis. 2012;71:761-7.

68. He W, Dai C, Li Y, Zeng G, Monga SP, Liu Y. Wnt/B-catenin signaling promotes renal interstitial fibrosis. J Am Soc Nephrol. 2009;20:765-76.

69. Kawano Y, Kypta R. Secreted antagonists of the Wnt signalling pathway. J Cell Sci. 2003;116:2627-34.

70. Acharya A, Baek ST, Huang G, Eskiocak B, Goetsch S, Sung CY, Banfi S, Sauer MF, Olsen GS, Duffield JS. The bHLH transcription factor Tcf21 is required for lineage-specific EMT of cardiac fibroblast progenitors. Development. 2012; 139:2139-49.

71. Sklepkiewicz P, Shiomi T, Kaur R, Sun J, Kwon S, Mercer B, Bodine P, Schermuly RT, George I, Schulze PC. Loss of secreted frizzled-related protein-1 leads to deterioration of cardiac function in mice and plays a role in human cardiomyopathy. Circ Heart Fail. 2015;8:362-72.

72. Ye B, Ge Y, Perens G, Hong L, Xu H, Fishbein MC, Li F. Canonical Wnt/Bcatenin signaling in epicardial fibrosis of failed pediatric heart allografts with diastolic dysfunction. Cardiovasc Pathol. 2013;22:54-7.

73. Lam AP, Herazo-Maya JD, Sennello JA, Flozak AS, Russell S, Mutlu GM, Budinger GS, DasGupta R, Varga J, Kaminski N. Wnt coreceptor Lrp5 is a driver of idiopathic pulmonary fibrosis. Am J Respir Crit Care Med. 2014;190:185-95.

74. Sundaresan NR, Bindu S, Pillai VB, Samant S, Pan Y, Huang J-Y, Gupta M, Nagalingam RS, Wolfgeher D, Verdin E. SIRT3 blocks aging-associated tissue fibrosis in mice by deacetylating and activating glycogen synthase kinase 33. Mol Cell Biol. 2016;36:678-92.

75. Liu W, Rui H, Wang J, Lin S, He Y, Chen M, Li Q, Ye Z, Zhang S, Chan SC. Axin is a scaffold protein in TGF- $\beta$ signaling that promotes degradation of Smad7 by Arkadia. EMBO J. 2006;25:1646-58.

76. Furuhashi M, Yagi K, Yamamoto H, Furukawa Y, Shimada S, Nakamura Y, Kikuchi A, Miyazono K, Kato M. Axin facilitates Smad3 activation in the transforming growth factor $\beta$ signaling pathway. Mol Cell Biol. 2001;21:5132-41.

77. Tan J, Tong B-D, Wu Y-J, Xiong W. MicroRNA-29 mediates TGF $\beta 1$-induced extracellular matrix synthesis by targeting wnt/ $\beta$-catenin pathway in human orbital fibroblasts. Int J Clin Exp Pathol. 2014;7:7571.

78. Warner D, Greene R, Pisano M. Interaction between Smad 3 and Dishevelled in murine embryonic craniofacial mesenchymal cells. Orthod Craniofac Res. 2005;8:123-30
79. Warner DR, Greene RM, Pisano MM. Cross-talk between the TGF $\beta$ and Wnt signaling pathways in murine embryonic maxillary mesenchymal cells. FEBS Lett. 2005;579:3539-46.

80. Xu L, Cui WH, Zhou WC, Li DL, Li LC, Zhao P, Mo XT, Zhang Z, Gao J. Activation of $\mathrm{Wnt} / \beta$-catenin signalling is required for TGF- $\beta / \mathrm{Smad} 2 / 3$ signalling during myofibroblast proliferation. J Cell Mol Med. 2017;21:1545-54.

81. Si Y, Bai J, Wu J, Li Q, Mo Y, Fang R, Lai W. LncRNA PIncRNA-1 regulates proliferation and differentiation of hair follicle stem cells through TGF- $\beta 1$ mediated Wnt/B-catenin signal pathway. Mol Med Rep. 2018;17:1191-7.

82. Plikus MV, Gay DL, Treffeisen E, Wang A, Supapannachart RJ, Cotsarelis G: Epithelial stem cells and implications for wound repair. In Seminars in cell \& developmental biology. Semin Cell Dev Biol. 2012;23(9):946-53.

83. Biswas H, Longmore GD. Action of SNAIL1 in cardiac myofibroblasts is important for cardiac fibrosis following hypoxic injury. PLoS One. 2016;11: e0162636.

84. Baudino TA, Carver W, Giles W, Borg TK. Cardiac fibroblasts: friend or foe? Am J Physiol Heart Circ Physiol. 2006;291:H1015-26.

85. Camelliti P, Borg TK, Kohl P. Structural and functional characterisation of cardiac fibroblasts. Cardiovasc Res. 2005;65:40-51.

86. Nag A. Study of non-muscle cells of the adult mammalian heart: a fine structural analysis and distribution. Cytobios. 1980;28:41-61.

87. Heymans S, González A, Pizard A, Papageorgiou AP, López-Andrés N, Jaisser F, Thum T, Zannad F, Díez J. Searching for new mechanisms of myocardial fibrosis with diagnostic and/or therapeutic potential. Eur J Heart Fail. 2015; 17:764-71.

88. Rathod RH, Powell AJ, Geva T. Myocardial fibrosis in congenital heart disease. Circ J. 2016;80:1300-7.

89. Tomasek JJ, Gabbiani G, Hinz B, Chaponnier C, Brown RA. Myofibroblasts and mechano-regulation of connective tissue remodelling. Nat Rev Mol Cell Biol. 2002;3:349.

90. Hinz B, Pittet P, Smith-Clerc J, Chaponnier C, Meister J-J. Myofibroblast development is characterized by specific cell-cell adherens junctions. Mol Biol Cell. 2004;15:4310-20.

91. Hinz B. Formation and function of the myofibroblast during tissue repair. J Investig Dermatol. 2007;127:526-37.

92. Cohn JN, Ferrari R, Sharpe N. Cardiac remodeling - concepts and clinical implications: a consensus paper from an international forum on cardiac remodeling. J Am Coll Cardiol. 2000;35:569-82.

93. Farah MCK, Castro CRP, de Melo MV, Binotto MA, Guerra VC, de Almeida RA, Marcial MB, Lopes AA, Mathias W Jr, Aiello VD. The impact of preexisting myocardial remodeling on ventricular function early after tetralogy of Fallot repair. J Am Soc Echocardiogr. 2010;23:912-8.

94. Ho SY, Jackson M, Kilpatrick L, Smith A, Gerlis LM. Fibrous matrix of ventricular myocardium in tricuspid atresia compared with normal heart: a quantitative analysis. Circulation. 1996;94:1642-6.

95. Moon JC, Messroghli DR, Kellman P, Piechnik SK, Robson MD, Ugander M, Gatehouse PD, Arai AE, Friedrich MG, Neubauer S. Myocardial T1 mapping and extracellular volume quantification: a Society for Cardiovascular Magnetic Resonance (SCMR) and CMR working Group of the European Society of cardiology consensus statement. J Cardiovasc Magn Reson. 2013;15:92.

96. McCrohon J, Moon J, Prasad S, McKenna W, Lorenz C, Coats A, Pennell D. Differentiation of heart failure related to dilated cardiomyopathy and coronary artery disease using gadolinium-enhanced cardiovascular magnetic resonance. Circulation. 2003;108:54-9.

97. Sanchez-Quintana D, Climent V, Ho S, Anderson R. Myoarchitecture and connective tissue in hearts with tricuspid atresia. Heart. 1999;81:182-91.

98. Chowdhury UK, Sathia S, Ray R, Singh R, Pradeep KK, Venugopal P. Histopathology of the right ventricular outflow tract and its relationship to clinical outcomes and arrhythmias in patients with tetralogy of Fallot. J Thorac Cardiovasc Surg. 2006;132:270-7 e274.

99. Cheitlin MD, Robinowitz M, McAllister H, Hoffman J, Bharati S, Lev M. The distribution of fibrosis in the left ventricle in congenital aortic stenosis and coarctation of the aorta. Circulation. 1980;62:823-30.

100. Izawa H, Murohara T, Nagata K, Isobe S, Asano H, Amano T, Ichihara S, Kato T, Ohshima S, Murase Y. Mineralocorticoid receptor antagonism ameliorates left ventricular diastolic dysfunction and myocardial fibrosis in mildly symptomatic patients with idiopathic dilated cardiomyopathy: a pilot study. Circulation. 2005:112:2940-5.

101. Willems I, Havenith MG, De Mey J, Daemen M. The alpha-smooth muscle actin-positive cells in healing human myocardial scars. Am J Pathol. 1994; 145:868. 
102. Sun Y, Weber KT. Infarct scar: a dynamic tissue. Cardiovasc Res. 2000;46:250-6.

103. Baum J, Duffy HS. Fibroblasts and myofibroblasts: what are we talking about? J Cardiovasc Pharmacol. 2011;57:376.

104. Santiago JJ, Dangerfield AL, Rattan SG, Bathe KL, Cunnington RH, Raizman JE, Bedosky KM, Freed DH, Kardami E, Dixon IM. Cardiac fibroblast to myofibroblast differentiation in vivo and in vitro: expression of focal adhesion components in neonatal and adult rat ventricular myofibroblasts. Dev Dyn. 2010;239:1573-84.

105. Leask A, Abraham DJ. TGF- $\beta$ signaling and the fibrotic response. FASEB J. 2004; 18:816-27.

106. Wang B, Omar A, Angelovska T, Drobic V, Rattan SG, Jones SC, Dixon IM. Regulation of collagen synthesis by inhibitory Smad7 in cardiac myofibroblasts. Am JPhysiol-Heart Circulatory Physiol. 2007;293:H1282-90.

107. Duan J, Gherghe C, Liu D, Hamlett E, Srikantha L, Rodgers L, Regan JN, Rojas $M$, Willis $M$, Leask $A$. Wnt1/ $\beta$ catenin injury response activates the epicardium and cardiac fibroblasts to promote cardiac repair. EMBO J. 2012; 31:429-42.

108. Kuwahara F, Kai H, Tokuda K, Kai M, Takeshita A, Egashira K, Imaizumi T. Transforming growth factor- $\beta$ function blocking prevents myocardial fibrosis and diastolic dysfunction in pressure-overloaded rats. Circulation. 2002;106: 130-5.

109. Shi Y, Massagué J. Mechanisms of TGF- $\beta$ signaling from cell membrane to the nucleus. Cell. 2003;113:685-700.

110. Dobaczewski M, Bujak M, Li N, Gonzalez-Quesada C, Mendoza LH, Wang XF, Frangogiannis NG. Smad3 signaling critically regulates fibroblast phenotype and function in healing myocardial infarction. Circ Res. 2010;107: 418-28.

111. Bujak M, Ren G, Kweon HJ, Dobaczewski M, Reddy A, Taffet G, Wang X-F, Frangogiannis NG. Essential role of Smad3 in infarct healing and in the pathogenesis of cardiac remodeling. Circulation. 2007;116:2127-38.

112. Verrecchia F, Chu M-L, Mauviel A. Identification of novel TGF- $\beta / S m a d$ gene targets in dermal fibroblasts using a combined CDNA microarray/promoter transactivation approach. J Biol Chem. 2001;276:17058-62.

113. Dobaczewski M, Gonzalez-Quesada C, Frangogiannis NG. The extracellular matrix as a modulator of the inflammatory and reparative response following myocardial infarction. J Mol Cell Cardiol. 2010;48:504-11.

114. Leask A. Potential therapeutic targets for cardiac fibrosis: TGF $\beta$, angiotensin, endothelin, CCN2, and PDGF, partners in fibroblast activation. Circ Res. 2010; 106:1675-80.

115. Schiller M, Javelaud D, Mauviel A. TGF- $\beta$-induced SMAD signaling and gene regulation: consequences for extracellular matrix remodeling and wound healing. J Dermatol Sci. 2004;35:83-92.

116. Serini G, Bochaton-Piallat M-L, Ropraz P, Geinoz A, Borsi L, Zardi L, Gabbiani $G$. The fibronectin domain ED-A is crucial for myofibroblastic phenotype induction by transforming growth factor- $\beta 1$. J Cell Biol. 1998;142:873-81.

117. Naugle JE, Olson ER, Zhang X, Mase SE, Pilati CF, Maron MB, Folkesson HG, Horne WI, Doane KJ, Meszaros JG. Type VI collagen induces cardiac myofibroblast differentiation: implications for postinfarction remodeling. Am JPhysiol-Heart Circulatory Physiol. 2006;290:H323-30.

118. Blyszczuk P, Müller-Edenborn B, Valenta T, Osto E, Stellato M, Behnke S, Glatz K, Basler K, Lüscher TF, Distler O. Transforming growth factor- $\beta$-dependent Wnt secretion controls myofibroblast formation and myocardial fibrosis progression in experimental autoimmune myocarditis. Eur Heart J. 2016;38: $1413-25$.

119. Ma Z-G, Yuan Y-P, Zhang X, Xu S-C, Wang S-S, Tang Q-Z. Piperine attenuates pathological cardiac fibrosis via PPAR- $\gamma / A K T$ pathways. EBioMedicine. 2017;18:179-87.

120. Wei J, Fang F, Lam AP, Sargent JL, Hamburg E, Hinchcliff ME, Gottardi CJ, Atit $\mathrm{R}$, Whitfield ML, Varga J. Wnt/B-catenin signaling is hyperactivated in systemic sclerosis and induces Smad-dependent fibrotic responses in mesenchymal cells. Arthritis Rheum. 2012;64:2734-45.

121. Tanjore H, Degryse AL, Crossno PF, XU XC, McConaha ME, Jones BR, Polosukhin W, Bryant AJ, Cheng D-S. Newcomb DC: $\beta$-catenin in the alveolar epithelium protects from lung fibrosis after intratracheal bleomycin. Am J Respir Crit Care Med. 2013;187:630-9.

122. Lal H, Ahmad F, Zhou J, Yu JE, Vagnozzi RJ, Guo Y, Yu D, Tsai EJ, Woodgett J, Gao E. Cardiac fibroblast glycogen synthase kinase-3 $\beta$ regulates ventricular remodeling and dysfunction in ischemic heart. Circulation. 2014; 130:419-30.

123. He W, Zhang L, Ni A, Zhang Z, Mirotsou M, Mao L, Pratt RE, Dzau VJ. Exogenously administered secreted frizzled related protein 2 (Sfrp2) reduces fibrosis and improves cardiac function in a rat model of myocardial infarction. Proc Natl Acad Sci. 2010;107:21110-5.

124. Mastri M, Shah Z, Hsieh K, Wang X, Wooldridge B, Martin S, Suzuki G, Lee T. Secreted Frizzled-related protein 2 as a target in antifibrotic therapeutic intervention. Am J Physiol-Cell Physiol. 2013;306:C531-9.

125. Kobayashi K, Luo M, Zhang Y, Wilkes DC, Ge G, Grieskamp T, Yamada C, Liu T-C, Huang G, Basson CT. Secreted Frizzled-related protein 2 is a procollagen $\mathrm{C}$ proteinase enhancer with a role in fibrosis associated with myocardial infarction. Nat Cell Biol. 2009;11:46.

126. Xiang F-L, Fang M, Yutzey KE. Loss of $\beta$-catenin in resident cardiac fibroblasts attenuates fibrosis induced by pressure overload in mice. Nat Commun. 2017:8:712.

127. C-g Z, Xu Y-y, Y-y T, Zhang Y, Chen W-Q, Ji X-P, Mao Y, Qiao L, Cheng J, Xu Q-B. DKK3 overexpression attenuates cardiac hypertrophy and fibrosis in an angiotensin-perfused animal model by regulating the ADAM17/ACE2 and

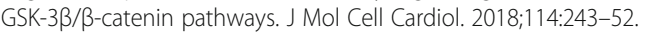

128. Zhao X, Hua Y, Chen H, Yang H, Zhang T, Huang G, Fan H, Tan Z, Huang X, Liu B. Aldehyde dehydrogenase-2 protects against myocardial infarctionrelated cardiac fibrosis through modulation of the Wnt/ $\beta$-catenin signaling pathway. Ther Clin Risk Manag. 2015;11:1371.

129. Paik DT, Rai M, Ryzhov S, Sanders LN, Aisagbonhi O, Funke MJ, Feoktistov I, Hatzopoulos AK. Wnt10b gain-of-function improves cardiac repair by arteriole formation and attenuation of fibrosis. Circ Res. 2015;117:804-16.

130. Qian L, Hong J, Zhang Y, Zhu M, Wang X, Zhang Y, Chu M, Yao J, Xu D. Downregulation of S100A4 Alleviates Cardiac Fibrosis via Wnt/ $\beta$-Catenin Pathway in Mice. Cell Physiol Biochem. 2018;46:2551-60.

131. Działo E, Rudnik M, Koning Rl, Czepiel M, Tkacz K, Baj-Krzyworzeka M, Distler O, Siedlar M, Kania G, Błyszczuk P. WNT3a and WNT5a Transported by Exosomes Activate WNT Signaling Pathways in Human Cardiac Fibroblasts. Int J Mol Sci. 2019;20:1436.

132. Zeng Z, Wang Q, Yang X, Ren Y, Jiao S, Zhu Q, Guo D, Xia K, Wang Y, Li C. Qishen Granule Attenuates Cardiac Fibrosis by Regulating TGF- $\beta / S m a d 3$ and GSK-3ß Pathway. Phytomedicine. 2019;62:152949.

133. Ma J, Li Z-Y, Liang X-P, Guo C-X, Lu P-P, Ma L-H. Xinfuli Granule improves post-myocardial infarction ventricular remodeling and myocardial fibrosis in rats by regulating TGF- $\beta /$ Smads signaling pathway. J Geriatric Cardiol. 2017; 14:301.

134. Green LC, Anthony SR, Slone S, Lanzillotta L, Nieman ML, Wu X, Robbins N, Jones SM, Roy S, Owens AP III. Human antigen R as a therapeutic target in pathological cardiac hypertrophy. JCI Insight. 2019;4(4):e121541.

135. Wang Z, Xu Y, Wang M, Ye J, Liu J, Jiang H, Ye D, Wan J. TRPA1 inhibition ameliorates pressure overload-induced cardiac hypertrophy and fibrosis in mice. EBioMedicine. 2018:36:54-62.

136. Zhao Y, Wang C, Wang C, Hong X, Miao J, Liao Y, Zhou L, Liu Y. An essential role for Wnt/ $\beta$-catenin signaling in mediating hypertensive heart disease. Sci Rep. 2018;8:8996.

137. Su S-A, Yang D, Wu Y, Xie Y, Zhu W, Cai Z, Shen J, Fu Z, Wang Y, Jia L. EphrinB2 regulates cardiac fibrosis through modulating the interaction of Stat3 and TGF-B/Smad3 signaling. Circ Res. 2017;121:617-27.

138. Gomes A, Nolasco S, Soares H. Non-coding RNAs: multi-tasking molecules in the cell. Int J Mol Sci. 2013;14:16010-39.

139. Li Z, Zhao W, Wang M, Zhou X: The Role of Long Noncoding RNAs in Gene Expression Regulation. In Gene Expression Profiling in Cancer. IntechOpen; 2019

140. Ebbesen KK, Hansen TB, Kjems J: Insights into circular RNA biology. RNA BIOLOGY 2017, 14:1035-1045.

141. Cortés-López M, Miura P. Focus: Epigenetics: Emerging Functions of Circular RNAs. Yale J Biol Med. 2016:89:527.

142. Qu S, Zhong Y, Shang R, Zhang X, Song W, Kjems J, Li H. The emerging landscape of circular RNA in life processes. RNA Biol. 2017;14:992-9.

143. Kosaka N, Izumi H, Sekine K. Ochiya T: microRNA as a new immuneregulatory agent in breast milk. Silence. 2010;1:7.

144. Ottaviani L, Sansonetti M, da Costa Martins PA. Myocardial cell-to-cell communication via microRNAs. Noncoding RNA Res. 2018:3(3):144-53.

145. Gupta SK, Bang C, Thum T. Circulating microRNAs as biomarkers and potential paracrine mediators of cardiovascular disease. Circ Cardiovasc Genet. 2010;3:484-8.

146. Viereck J, Bang C, Foinquinos A, Thum T. Regulatory RNAs and paracrine networks in the heart. Cardiovasc Res. 2014;102:290-301.

147. Hergenreider E, Heydt S, Tréguer K, Boettger T, Horrevoets AJ, Zeiher AM, Scheffer MP, Frangakis AS, Yin X, Mayr M. Atheroprotective communication 
between endothelial cells and smooth muscle cells through miRNAs. Nat Cell Biol. 2012;14:249.

148. Sahoo S, Losordo DW. Exosomes and cardiac repair after myocardial infarction. Circ Res. 2014;114:333-44.

149. Chen S, Puthanveetil P, Feng B, Matkovich SJ, Dorn GW, Chakrabarti S. Cardiac miR-133a overexpression prevents early cardiac fibrosis in diabetes. J Cell Mol Med. 2014;18:415-21.

150. Puthanveetil P, Chen S, Feng B, Gautam A, Chakrabarti S. Long non-coding RNA MALAT 1 regulates hyperglycaemia induced inflammatory process in the endothelial cells. J Cell Mol Med. 2015;19:1418-25.

151. Feng B, Chen S, George B, Feng Q. Chakrabarti S: miR133a regulates cardiomyocyte hypertrophy in diabetes. Diabetes Metab Res Rev. 2010; 26:40-9.

152. Chen Y, Wakili R, Xiao J, Wu C-T, Luo X, Clauss S, Dawson K, Qi X, Naud P, Shi Y-F. Detailed characterization of microRNA changes in a canine heart failure model: Relationship to arrhythmogenic structural remodeling. J Mol Cell Cardiol. 2014;77:113-24.

153. Beaumont J, Lopez B, Hermida N, Schroen B, San José G, Heymans S, Valencia F, Gómez-Doblas JJ, De Teresa E. Diez J: microRNA-122 downregulation may play a role in severe myocardial fibrosis in human aortic stenosis through TGF- $\beta 1$ up-regulation. Clin Sci. 2014;126:497-506.

154. Van Rooij E, Sutherland LB, Thatcher JE, DiMaio JM, Naseem RH, Marshall WS, Hill JA, Olson EN. Dysregulation of microRNAs after myocardial infarction reveals a role of miR-29 in cardiac fibrosis. Proc Natl Acad Sci. 2008;105:13027-32.

155. Chiasson V, Takano APC, Guleria RS, Gupta S. Deficiency of Micro RNA miR1954 Promotes Cardiac Remodeling and Fibrosis. J Am Heart Assoc. 2019;8: e012880.

156. Fan $X$, Weng $X$, Zhao $Y$, Chen W, Gan T, Xu D. Circular RNAs in cardiovascular disease: an overview. Biomed Res Int. 2017;2017:5135781.

157. Panda AC, Grammatikakis I, Munk R, Gorospe M, Abdelmohsen K. Emerging roles and context of circular RNAs. Wiley Interdisciplinary Reviews: RNA. 2017;8:e1386.

158. Ni H, Li W, Zhuge Y, Xu S, Wang Y, Chen Y, Shen G, Wang F. Inhibition of circHIPK3 prevents angiotensin II-induced cardiac fibrosis by sponging miR29b-3p. Int J Cardiol. 2019;292:188-96.

159. Ma Y, Yang Y, Wang F, Moyer M-P, Wei Q, Zhang P, Yang Z, Liu W, Zhang $H_{\text {, }}$ Chen N. Long non-coding RNA CCAL regulates colorectal cancer progression by activating Wnt/ $\beta$-catenin signalling pathway via suppression of activator protein 2a. Gut. 2016:65:1494-504.

160. Wu Z, Li Y, Wu Y, Wang Y, Nian W, Wang L, Li L, Luo H, Wang D. Long noncoding RNA CCAT2 promotes the breast cancer growth and metastasis by regulating TGF-beta signaling pathway. Eur Rev Med Pharmacol Sci. 2017;21: 706-14.

161. Shan Z, An N, Qin J, Yang J, Sun H, Yang W. Long non-coding RNA Linc00675 suppresses cell proliferation and metastasis in colorectal cancer via acting on miR-942 and Wnt/B-catenin signaling. Biomed Pharmacother. 2018;101:769-76.

162. Yuan Z, Yu X, Ni B, Chen D, Yang Z, Huang J, Wang J, Chen D, Wang L. Overexpression of long non-coding RNA-CTD903 inhibits colorectal cancer invasion and migration by repressing $W n t / \beta$-catenin signaling and predicts favorable prognosis. Int J Oncol. 2016;48:2675-85.

163. Wang $Y$, He L, Du Y, Zhu P, Huang G, Luo J, Yan X, Ye B, Li C, Xia P. The long noncoding RNA IncTCF7 promotes self-renewal of human liver cancer stem cells through activation of Wnt signaling. Cell Stem Cell. 2015;16:413-25.

164. Yu Y, Kanwar SS, Patel BB, Oh P-S, Nautiyal J, Sarkar FH, Majumdar AP. MicroRNA-21 induces stemness by downregulating transforming growth factor beta receptor 2 (TGFßR2) in colon cancer cells. Carcinogenesis. 2012; 33:68-76.

165. Yu F, Lu Z, Huang K, Wang X, Xu Z, Chen B, Dong P, Zheng J. MicroRNA-17$5 p$-activated $W n t / \beta$-catenin pathway contributes to the progression of liver fibrosis. Oncotarget. 2016;7:81.

166. Liang H, Zhang C, Ban T, Liu Y, Mei L, Piao X, Zhao D, Lu Y, Chu W, Yang B. A novel reciprocal loop between microRNA-21 and TGFBRIII is involved in cardiac fibrosis. Int J Biochem Cell Biol. 2012;44:2152-60.

167. Patrick DM, Montgomery RL, Qi X, Obad S, Kauppinen S, Hill JA, van Rooij E, Olson EN. Stress-dependent cardiac remodeling occurs in the absence of microRNA-21 in mice. J Clin Invest. 2010;120:3912-6.

168. Pan Z, Sun X, Shan H, Wang N, Wang J, Ren J, Feng S, Xie L, Lu C, Yuan Y. MicroRNA-101 inhibited postinfarct cardiac fibrosis and improved left ventricular compliance via the FBJ osteosarcoma oncogene/transforming growth factor- $\beta 1$ pathway. Circulation. 2012;126:840-50.

169. Shan H, Zhang Y, Lu Y, Zhang Y, Pan Z, Cai B, Wang N, Li X, Feng T, Hong Y. Downregulation of miR-133 and miR-590 contributes to nicotine-induced atrial remodelling in canines. Cardiovasc Res. 2009;83:465-72.

170. Boon RA, Seeger T, Heydt S, Fischer A, Hergenreider E, Horrevoets AJ, Vinciguerra M, Rosenthal N, Sciacca S, Pilato M. MicroRNA-29 in aortic dilation: implications for aneurysm formation. Circ Res. 2011;109:1115-9.

171. He W, Huang H, Xie Q, Wang Z, Fan Y, Kong B, Huang D, Xiao Y. MiR-155 knockout in fibroblasts improves cardiac remodeling by targeting tumor protein p53-inducible nuclear protein 1. J Cardiovasc Pharmacol Ther. 2016; 21:423-35.

172. Peuget S, Bonacci T, Soubeyran P, lovanna J, Dusetti N. Oxidative stressinduced p53 activity is enhanced by a redox-sensitive TP53INP1 SUMOylation. Cell Death Differ. 2014:21:1107.

173. Liu F, Kong $X$, Lv L, Gao J. TGF- $\beta 1$ acts through miR-155 to down-regulate TP53INP1 in promoting epithelial-mesenchymal transition and cancer stem cell phenotypes. Cancer Lett. 2015;359:288-98.

174. Wang J, Huang W, Xu R, Nie Y, Cao X, Meng J, Xu X, Hu S, Zheng Z. Micro RNA-24 regulates cardiac fibrosis after myocardial infarction. J Cell Mol Med. 2012;16:2150-60.

175. Ornatowski W, Poschet JF, Perkett E, Taylor-Cousar JL, Deretic V. Elevated furin levels in human cystic fibrosis cells result in hypersusceptibility to exotoxin A-induced cytotoxicity. J Clin Invest. 2007;117:3489-97.

176. Qu X, Du Y, Shu Y, Gao M, Sun F, Luo S, Yang T, Zhan L, Yuan Y, Chu W. MIAT is a pro-fibrotic long non-coding RNA governing cardiac fibrosis in post-infarct myocardium. Sci Rep. 2017;7:42657.

177. Seo H-H, Lee S, Lee CY, Lee J, Shin S, Song B-W, Kim I-K, Choi J-W, Lim S, Kim SW. Multipoint targeting of TGF- $\beta$ /Wnt transactivation circuit with microRNA 384-5p for cardiac fibrosis. Cell Death Differ. 2019;26(6):1107-23.

178. Zhou B, Yu J-W. A novel identified circular RNA, circRNA_010567, promotes myocardial fibrosis via suppressing miR-141 by targeting TGF- $\beta 1$. Biochem Biophys Res Commun. 2017;487:769-75

179. Nagalingam RS, Sundaresan NR, Noor M, Gupta MP, Solaro RJ, Gupta M. Deficiency of cardiomyocyte-specific microRNA-378 contributes to the development of cardiac fibrosis involving a transforming growth factor $\beta$ (TGFß1)-dependent paracrine mechanism. J Biol Chem. 2014;289:27199-214.

180. Zhao X, Wang K, Liao Y, Zeng Q, Li Y, Hu F, Liu Y, Meng K, Qian C, Zhang Q. MicroRNA-101a inhibits cardiac fibrosis induced by hypoxia via targeting TGFßRI on cardiac fibroblasts. Cell Physiol Biochem. 2015;35:213-26.

181. Zhao N, Koenig SN, Trask AJ, Lin C-H, Hans CP, Garg V, Lilly B. MicroRNA miR145 regulates TGFBR2 expression and matrix synthesis in vascular smooth muscle cells. Circ Res. 2015;116:23-34.

182. Wang L, Jiang P, He Y, Hu H, Guo Y, Liu X, Qiu H, Ma Q, Ouyang F. A novel mechanism of Smads/miR-675/TGF $\beta R 1$ axis modulating the proliferation and remodeling of mouse cardiac fibroblasts. J Cell Physiol. 2019;234(11): 20275-85.

183. Li P-F, He R-H, Shi S-B, Li R, Wang Q-T, Rao G-T, Yang B. Modulation of miR10a-mediated TGF- $\beta 1 /$ Smads signaling affects atrial fibrillation-induced cardiac fibrosis and cardiac fibroblast proliferation. Biosci Rep. 2019;39: BSR20181931.

184. Tijsen AJ, van der Made I, van den Hoogenhof MM, Wijnen WJ, van Deel ED, de Groot NE, Alekseev S, Fluiter K, Schroen B, Goumans M-J. The microRNA-15 family inhibits the TGF $\beta$-pathway in the heart. Cardiovasc Res. 2014;104:61-71.

185. Li J, Dai Y, Su Z, Wei G. MicroRNA-9 inhibits high glucose-induced proliferation, differentiation and collagen accumulation of cardiac fibroblasts by down-regulation of TGFBR2. Biosci Rep. 2016;36:e00417.

186. Liu X, Xu Y, Deng Y, Li H. MicroRNA-223 regulates cardiac fibrosis after myocardial infarction by targeting RASA1. Cell Physiol Biochem. 2018;46: 1439-54.

187. Zhang J, Lang Y, Guo L, Pei Y, Hao S, Liang Z, Su G, Shu L, Liu H, Huang C. MicroRNA-323a-3p Promotes Pressure Overload-Induced Cardiac Fibrosis by Targeting TIMP3. Cell Physiol Biochem. 2018;50:2176-87.

188. Wu H-Y, Wu J-L, Ni Z-L. Overexpression of microRNA-202-3p protects against myocardial ischemia-reperfusion injury through activation of TGF$\beta 1 /$ Smads signaling pathway by targeting TRPM6. Cell Cycle. 2019;18(5): 621-37.

189. Tao L, Bei Y, Chen P, Lei Z, Fu S, Zhang H, Xu J, Che L, Chen X, Sluijter JP. Crucial role of miR-433 in regulating cardiac fibrosis. Theranostics. 2016;6:2068. 
190. Zhu J-N, Chen R, Fu Y-H, Lin Q-X, Huang S, Guo L-L, Zhang M-Z, Deng C-Y, Zou X, Zhong S-L. Smad3 inactivation and MiR-29b upregulation mediate the effect of carvedilol on attenuating the acute myocardium infarctioninduced myocardial fibrosis in rat. PLoS One. 2013;8:e75557.

191. Wang X, Jin H, Jiang S, Xu Y. MicroRNA-495 inhibits the high glucoseinduced inflammation, differentiation and extracellular matrix accumulation of cardiac fibroblasts through downregulation of NOD1. Cell Mol Biol Lett. 2018;23:23.

192. Dong P, Liu W, Wang D. MiR-154 promotes myocardial fibrosis through $\beta$ catenin signaling pathway. Eur Rev Med Pharmacol Sci. 2018;22:2052-60.

193. Sun LY, Bie ZD, Zhang CH, Li H, Li LD, Yang J. MiR-154 directly suppresses DKK2 to activate Wnt signaling pathway and enhance activation of cardiac fibroblasts. Cell Biol Int. 2016;40:1271-9.

194. Chen M, Liu J, Liu Y, Hu Y, Cai X, Yin D. MicroRNA-199a regulates myocardial fibrosis in rats by targeting SFRP5. Eur Rev Med Pharmacol Sci. 2019;23: 3976-83.

195. Zhou Y, Deng L, Zhao D, Chen L, Yao Z, Guo X, Liu X, Lv L, Leng B, Xu W. Micro RNA-503 promotes angiotensin II-induced cardiac fibrosis by targeting Apelin-13. J Cell Mol Med. 2016;20:495-505.

196. Wang X, Yong C, Yu K, Yu R, Zhang R, Yu L, Li S, Cai S. Long noncoding RNA (IncRNA) n379519 promotes cardiac fibrosis in post-infarct myocardium by targeting miR-30. Med Sci Monitor Int Med J Experimental Clin Res. 2018; 24:3958.

197. Zhu Y, Feng Z, Jian Z, Xiao Y. Long noncoding RNA TUG1 promotes cardiac fibroblast transformation to myofibroblasts via miR-29c in chronic hypoxia. Mol Med Rep. 2018;18:3451-60

198. Wang J, Liu X, Zhuang Q, Pan R, Zou L, Cen Z, Tang L. Long noncoding RNA homeobox A11 antisense promotes transforming growth factor $\beta 1$ induced fibrogenesis in cardiac fibroblasts. Mol Med Rep. 2019;19:2817-24.

199. Zheng D, Zhang Y, Hu Y, Guan J, Xu L, Xiao W, Zhong Q, Ren C, Lu J, Liang J, Hou J. Long noncoding RNA Crnde attenuates cardiac fibrosis via Smad3Crnde negative feedback in diabetic cardiomyopathy. FEBS J. 2019;286: $1645-55$.

\section{Publisher's Note}

Springer Nature remains neutral with regard to jurisdictional claims in published maps and institutional affiliations.

Ready to submit your research? Choose BMC and benefit from:

- fast, convenient online submission

- thorough peer review by experienced researchers in your field

- rapid publication on acceptance

- support for research data, including large and complex data types

- gold Open Access which fosters wider collaboration and increased citations

- maximum visibility for your research: over $100 \mathrm{M}$ website views per year

At $\mathrm{BMC}$, research is always in progress.

Learn more biomedcentral.com/submissions 